\title{
The Institutional Memory Hypothesis and the Procyclicality of Bank Lending Behavior
}

\author{
Allen N. Berger \\ Board of Governors of the Federal Reserve System \\ Washington, DC 20551 U.S.A. \\ Wharton Financial Institutions Center \\ Philadelphia, PA 19104 U.S.A. \\ aberger@,frb.gov \\ Gregory F. Udell \\ Kelley School of Business, Indiana University \\ Bloomington, IN 47405 U.S.A. \\ gudell@indiana.edu
}

December 2002

\begin{abstract}
$\underline{\text { Abstract }}$
Stylized facts suggest that bank lending behavior is highly procyclical. We offer a new hypothesis that may help explain why this occurs. The institutional memory hypothesis is driven by deterioration in the ability of loan officers over the bank's lending cycle that results in an easing of credit standards. This easing of standards may be compounded by simultaneous deterioration in the capacity of bank management to discipline its loan officers and reduction in the capacities of external stakeholders to discipline bank management. We test the empirical implications of this hypothesis using data from individual U.S. banks over the period 1980-2000. We employ over 200,000 observations on commercial loan growth measured at the bank level, over 2,000,000 observations on interest rate premiums on individual loans, and over 2,000 observations on credit standards and bank-level loan spreads from bank management survey responses. The empirical analysis provides support for the hypothesis.
\end{abstract}

JEL classification codes: G21, G28, E32, E44

Key words: Banks, Lending, Business Cycles

The opinions expressed do not necessarily reflect those of the Federal Reserve Board or its staff. The authors thank Viral Acharya, Bob Avery, Bill Bassett, Charlie Calomiris, Andrew Ellul, Bill English, Arturo Estrella, Linda Goldberg, Michael Gordy, Diana Hancock, Dick Herring, Bev Hirtle, Myron Kwast, Philip Lowe, Cara Lown, Jamie McAndrews, Don Morgan, Rich Rosen, Eric Rosengren, Lisa Ryu, Til Schuermann, Richard Shockley, Dave Skidmore, Scott Smart, Kevin Stiroh, Jon Zinman, and participants in the BIS conference on "Changes in Risk Through Time: Measurement and Policy Responses," the FDIC "Day of Risk" conference, and a seminar at the New York Federal Reserve Bank for helpful suggestions, and Nate Miller for outstanding research assistance.

Please address correspondence to Allen N. Berger, Mail Stop 153, Federal Reserve Board, 20th and C Streets. NW, Washington, DC 20551, call 202-452-2903, fax 202-452-5295, or email aberger@frb.gov 


\section{Institutional Memory, the Business Cycle, and Bank Lending Behavior}

\section{Introduction}

The linkage between the financial system and the business cycle has been the subject of much investigation. Arguments that the financial system is procyclical are quite consistent with economic events, such as the credit crunch in the U.S. during the early 1990s, the Russian and Asian financial crises in the late 1990s, and the large corporate bankruptcies of the early 2000s. Many theories focus on the increase and decrease in the supply of bank credit over the business cycle in order to explain two stylized facts widely observed by regulators, practitioners, and researchers. One stylized fact is that lending often increases significantly during business cycle expansions, and then falls considerably during subsequent downturns, sometimes dramatically enough to be labeled a "credit crunch." These changes in lending are generally more than proportional to the changes in economic activity, suggesting that they are changes in bank loan supply that tend to accentuate the business cycle.

A second stylized fact about bank loan procyclicality is that observed measures of loan performance problems appear to follow a distinct pattern over the business cycle. Past due, nonaccrual, provisions, and chargeoffs are generally very low during most of the expansion, start to appear at the end of the expansion, then rise dramatically during the downturn. This suggests that banks may take significantly more risks during the expansion, but these risks are revealed only later because it takes time for loan performance problems to appear.

Consistent with these stylized facts, Federal Reserve Chairman Alan Greenspan noted that regulators agree that "the worst loans are made at the top of the business cycle." (Chicago Bank Structure Conference May 10, 2001). Practitioners often echo this sentiment as reflected in a recent trade publication, "Human nature being what it is, lenders and borrowers frequently assume that strong growth will continue unabated. Loans made towards the end of an economic cycle are often underwritten based upon unrealistic assumptions concerning growth." (Furth 2001, p. 31). Greenspan also noted that at the bottom of the cycle, "the problem is not making bad loans ... it is not making any loans, whether good or bad, to credit-worthy customers," consistent with the sometimes dramatic fall in lending during the cyclical downturns. These stylized facts are also consistent with data from the Federal Reserve's Senior Loan Officer Survey (SLOS), which suggest that the senior managers of large U.S. banks report that they ease and tighten their credit standards over the business cycle, even after controlling for changes in demand (Lown, Morgan, and Rohatgi 2000, Jordan, Peek, and Rosengren 2002, Lown and Morgan 2002). Timing patterns consistent with these stylized facts are also evident in other nations, as shown in recent research (e.g., Borio, Furfine, and Lowe 2001, Horvath 2002, Borio and Lowe 2002). The stylized facts 
thus suggest that the seeds of loan performance problems are sown during an economic expansion when lower quality loans are made, and then these problems are revealed during the downturn.

The specific causes behind these fluctuations in bank loan supply and performance are the subject of considerable debate. In this paper, we offer and test a new hypothesis that may explain in part why bank lending follows this procyclical pattern. We hypothesize that "institutional memory" problems may drive a pattern of business lending that is associated with a deterioration in the ability of a bank to recognize potential loan problems and an easing of credit standards over its own loan cycle. Specifically, lending institutions may tend to forget the lessons they learned from their problem loans as time passes from their last loan "bust." The deterioration in loan officer ability is partly due to a proportional increase in officers that have never experienced a loan bust, and partly due to the atrophying skills of experienced officers as time passes since their last experience with problem loans. This deterioration in loan officer skills results in an easing of credit standards as officers become less able to differentiate lower-quality borrowers from higher-quality borrowers. This loss of institutional memory may be compounded by a simultaneous reduction in the capacity of the bank's internal monitoring system (loan review) to evaluate and discipline individual loan officers as time passes since the bank's last bust because there are fewer observed problem loans to use in evaluating loan officers. As well, the capacity of external stakeholders (e.g., subordinated debt holders, equity holders, government regulators and supervisors) to evaluate and control bank managers may also be substantially weakened as time passes since the bank's last bust due to the lack of observed loan performance problems. Although the institutional memory hypothesis is rooted in the bank's own loan performance problems rather than the aggregate business cycle, this hypothesis may help explain the stylized facts about bank lending over the aggregate cycle because banks tend to experience problem loans simultaneously.

The loss of institutional memory may have a number of adverse consequences. First, the procyclical lending behavior it produces can exacerbate the business cycle and increase systemic risk. This problem may be especially serious for developing countries with relatively fragile and less well-regulated banking systems (Mero 2002). Second, the procyclical lending behavior could result in a significant misallocation of resources if a significant number of negative net present value (NPV) loans are extended during an expansion and positive NPV loans are denied during a downturn. Third, the cyclicality of problem loans may make it difficult for government regulators and supervisors, as well as other external stakeholders, to discipline banks because of the lagged nature of problem loans. 
The institutional memory hypothesis implies that banks ease their credit standards as time passes since their last loan bust. Our main tests of this easing of credit standards examine whether a bank increases its commercial lending as time passes since its last bust, controlling for other factors affecting the demand for and supply of its credit. This increase in the supply of bank credit is a necessary condition of the institutional memory hypothesis as an explanation of the stylized facts about bank lending over the aggregate business cycle. We also run related tests of whether banks reduce their loan interest rate premiums and whether their senior management reports easing their standards and loan spreads as time passes since the bank's last loan bust.

The models are estimated using data from individual U.S. banks over the period 1980-2000 approximately two full business cycles. The dependent variables are taken from three different data sets - over 200,000 observations on commercial loan growth measured at the bank level from the Call Report, over 2,000,000 observations on interest rate premiums on individual loans from the Federal Reserve's Survey of Terms of Bank Lending, and over 2,000 observations on credit standards and bank-level loan spreads from responses to the Federal Reserve's Senior Loan Officer Survey. The key exogenous variable - the number of years since the bank's last bust - is measured as the time since the ratio of the allowance for loan and lease losses to total loans was at its maximum over an interval that includes the current year and the prior 10 years.

The regressions include a number of control variables to account for other factors affecting the demand for and supply of bank credit. We include bank fixed effects in all of our tests and also run the tests both with and without time fixed effects. The inclusion of time fixed effects makes the tests quite stringent because the findings for the key exogenous variable are based only on the variation in the bank's boom-and-bust-cycle that is not correlated with the aggregate cycle and other factors that change systematically over time. The time fixed effects also help control for the other hypotheses of procyclicality to the extent that these other hypotheses are driven by or correlated with the aggregate business cycle or other overall economic conditions.

The remainder of our paper is organized as follows. In the next section, we explain the institutional memory hypothesis. In Section 3, we review the extant literature on procyclicality in lending and how it relates to the new hypothesis. In Section 4, we discuss the empirical methodology, variables, and data sets. We present our empirical results in Section 5, and offer some conclusions in Section 6.

\section{The institutional memory hypothesis}

Under the institutional memory hypothesis, the capacity of loan departments to evaluate risk and identify 
potential future problems deteriorates as time passes since their last "learning experience" with problem loans. Early in a bank's lending cycle (i.e., immediately after a loan bust) the lessons of the bank's last bust are still fresh in the memory of loan officers who have just witnessed the ex post realization of their prior loan decisions. These lessons include learning about the association between firm characteristics and risk, the success of different contract structures, the efficacy of different monitoring methods, and the best strategies for managing distressed credits to mitigate losses. Thus, as the bank starts its rebound from its most recent experience with problem loans, the reservoir of lending knowledge is at its peak because these lessons are fresh in the minds of those loan officers who survived the experience. These lessons may be particularly important for loans to informationally opaque small businesses, which are often based more on "soft" information about the character and reliability of the firm's management team, the firm's relationships with customers and suppliers, the local business environment, etc.

As time passes since the bank's last loan bust, the level of loan officer skill tends to deteriorate -the officers do a worse job of screening, analyzing, and structuring their loans as they are originated, monitoring them after origination, and designing and implementing work-out strategies when these loans become distressed. One factor that may drive this deterioration is a decrease in the fraction of experienced loan officers. New loan officers are hired and trained to replace experienced officers who leave the bank or are promoted to senior positions elsewhere in the bank. These new officers have not had the learning experience of a loan portfolio bust. Additional new loan officers may also be hired to service increased loan demand as time passes since the bank's last bust, further reducing the average experience of the staff. Of these new loan officers, some may have the talent, perceptiveness, and initiative to overcome their lack of experience, but others may not. Another factor driving the deterioration in loan officer ability is the atrophy of lending skills by some individual loan officers who have had the experience of a loan bust, but haye begun to forget the lessons of the past. Arguably, this may affect some experienced officers more than others. ${ }^{1}$

Under the institutional memory hypothesis, this deterioration in loan officer ability may result in an easing of credit standards as officers become less able to recognize potential loan problems and lower-quality borrowers

\footnotetext{
${ }^{1}$ To the best of our knowledge, we are the first to articulate the institutional memory hypothesis as a theory of lending behavior. Some reference, however, has been made in the literature to the possibility that senior management experience with a prior financial crisis may have helped the Australian banking system weather the depression of the 1930s (Butlin and Boyce 1985, Fisher and Kent 1999). While this argument bears some resemblance to a type of institutional memory, it is focused on the overall skills of senior management while our institutional memory hypothesis focuses on changes in loan officer skills.
} 
become less differentiable from higher-quality borrowers. As a consequence, banks may pool lqan applicants that might otherwise be rejected with acceptable credits and extend credit to additional borrowers. ${ }^{2}$

Eventually, a bank's loan boom turns to a bust and its loan officers turn more of their attention to managing their distressed credits. This process of addressing loan problems helps restore institutional memory as officers "re-learn" how to make good loans, how to monitor them, and how to avoid making bad loans. Specifically, loan officers will learn which combinations of loan contract terms (e.g., business collateral, personal collateral, głarantees, covenants, maturity, etc.) and monitoring strategies (e.g., frequency of borrower contact, field exams, ${ }^{3}$ frequency and intensity of collateral reporting) used during the bank's boom minimized losses during its bust.

Perhaps more important, loan officers learn which contract terms and monitoring strategies failed to minimize losses. That is, they learn which combinations of contract terms were least effective in mitigating the adverse selection problem and which monitoring strategies were least effective in mitigating the moral hazard problem through early detection of deteriorating credits and fraud. ${ }^{4}$

As a consequence of the restoration of institutional memory during the bust, banks tighten their credit standards, as they are able to do a better job of separating lower-quality credits from higher-quality credits. By separating these pools, banks are able to reject some uncreditworthy borrowers they would have otherwise been accepted during the boom. ${ }^{5}$

The bank's internal loan auditing system, loan review, would seem to offer at least a partial solution to the problem of eased credit standards during a boom period. Banks invest in their loan review function in order to

\footnotetext{
${ }^{2}$ U.S. bank supervisors apparently concluded that banks reduced their credit standards on commercial loans near the end of the last business cycle. In a series of statements, the agencies expressed concerns over weakening lending standards, including the use of "enterprise value lending," under which lenders consider the value of the firm as a secondary source of repayment. Supervisors judge this to be an aggressive form of lending because it is based on a "going concern" assumption, and because a future faltering of cash flow simultaneously erodes both the lender's primary and secondary source of repayment (see Office of the Comptroller et al. 2001).

${ }^{3}$ For many risky commercial loans, banks send their own "field examiners" to audit the books and records of the borrower rather than just relying on their customer's auditor (see Kerwin 1994).

${ }^{4}$ Fraud-driven loan losses have recently received considerable attention in the national press. However, fraud has always been a major source of commercial loan losses and a major focus of prudent commercial loan management. While hard quantitative and statistical techniques can be useful in detecting fraud (Beneish 1999), early detection of fraud by commercial lenders is substantially dependent on more qualitative soft factors such as the character of the owner or manager of the firm (Udell 2002, Chapter 12).

${ }^{5}$ The bank may further reduce the supply of credit during the bust because loan officer time is reallocated away from making new loans and toward loan work-outs.
} 
assess the quality and performance of their loan officers. Loan review accomplishes this through costly monitoring of each loan officer's loan portfolio (Udell 1989). While some hard information about borrowers (e.g., financial ratios, collateral values, loan covenant violations) is helpful in this effort, it may be difficult for management to fully assess loan officer ability and effort through loan review exclusively on the basis of hard information about each lender's borrowers. It is particularly difficult when these borrowers are informationally opaque and their loans are based substantially on soft information. As a result, loan review relies heavily on drawing inferences about each loan officer's ability and effort based on the ex post performance of loans made by each individual loan officer. The loan review process includes analyses of 1) whether the ex ante structure of a loan officer's loans helped reduce the occurrence of problem loans and mitigated losses when problems subsequently occurred, 2) the frequency of problem loans for each loan officer, 3) whether problem loans were detected sufficiently early by the loan officer; and 4) whether appropriate and timely intervention/renegotiation strategies were implemented. The loan review evaluation helps reveal each loan officer's ability and effort, and thus reduce the costs associated with the agency problem between loan officers and senior management.

However, the capacity of loan review to perform this function is likely to diminish as time passes since the bank's last bust because there are fewer observed problem loans to use in evaluating loan officers. That is, at the same time that loan officer skills are deteriorating, the agency problem between loan officers and bank management worsens, making the loan review process less effective.

Bank management could offset some of this decline in credit standards by adjusting their internal lending policies that are linked to hard information. For instance, management could reduce the amount of credit authority delegated to its loan officers over the course of the lending cycle to partially offset the decline in credit standards associated with the loss of institutional memory. Similarly, bank management could impose an incremental premium on loan interest rates or collateral requirements on observable classes of loans to compensate for the unobserved lower quality credits that are likely to be included in these classes. The impact of such blunt policy instruments is complicated by the fact that new loan officers learn at unobservably different rates and that the atrophy of lending skills across experienced loan officers occurs at unobservably different rates. Such policies also run the risk of penalizing many good borrowers and destroying bank-borrower relationships that might otherwise be very profitable over the long run.

To avoid destroying otherwise profitable bank-borrower relationships, banks could instead tacitly allow 
their loan officers to ease credit standards and make negative NPV loans during the boom, and wait until the next bust when they can sort out the good officers from the bad officers. Preserving these bank-borrower relationships over the long run may be a value-maximizing strategy for some banks, even though it involves some negative NPV loans in the short run.

Agency problems between bank management and outside stakeholders may also worsen as time passes since the bank's last bust. Government regulators and supervisors, subordinated debtholders, outside shareholders, and other external stakeholders have even less information about the condition of the bank's borrowers and the loan demand it faces than does bank management. Thus, they may also need to observe loan performance problems to infer bank quality and bank management quality, but face the same problem as bank management - too few observable problem loans on which to make inferences when time has passed since the bank's last bust.

This additional layer of agency problems could reduce the incentive for bank managers to implement policies that address the unobservable deterioration in the bank's loan portfolio over the lending cycle. For example, these problems might discourage bank managers from imposing the type of rationing and pricing policies discussed above because its implementation would likely result in the bank reporting lower profits in the short run than observably comparable banks. It may be optimal for some bank managers to hide the quality of their loan officer staff and their own loan review effort from outside claimants by avoiding the implementation of these blunt instruments. Similarly, bank managers may choose herding or assume correlated risks in order to avoid the costs of separating themselves from their peers (e.g., Devenow and Welch 1996, Acharya 2001). Other managers may assume more unobservable risk (by not constraining their loan officers) in order to mimic unobservably stronger banks (Gorton and Rosen 1995). It also may not be in the best interest of these outside stakeholders to discipline bank managers to impose blunt policies on its loan officers if these policies would be value-reducing by destroying bank-borrower relationships.

Some factors suggest that the institutional memory hypothesis might apply more to large banks while other factors suggest it may apply more to small banks. On the one hand, large banks usually have a greater separation of ownership and control and more layers of separation between management and the individual loan officers than small banks. These characteristics would tend to increase agency costs and may exacerbate the institutional memory problem. On the other hand, small banks tend to make proportionately more relationship 
loans to informationally opaque borrowers in which institutional memory is relatively important. Large banks may be less inclined to make such loans because they are at an organizational disadvantage because the soft information about these loan applicants cannot be easily transmitted to or observed by senior management (Stein 2002). However, large borrowers can also be informationally opaque as suggested by empirical evidence (Carey, Prowse, Rea, and Udell 1993) and recent anecdotal evidence (e.g., Adelphia, Enron, Global Crossing, Rite Aid, and WorldCom). Nonetheless, many large borrowers have access to public capital markets and can, therefore, move in and out of bank finance at different points in the business cycle (e.g., Kashyap, Stein, and Wilcox 1993, Einarsson and Marquis 2001). This implies that 1) these borrowers may be less affected by the banking industry's institutional memory problem, and 2) the data on quantities and prices of large loans may be subject to significant selection bias as large firms move in and out of bank loans. In our empirical analysis, we will distinguish where possible by bank size and loan size.

\section{The related literature on bank procyclicality}

Much of the research on procyclicality has focused on credit crunches during business cycle downturns, particularly on the credit crunch in the early 1990s in the U.S. and elsewhere. A number of hypotheses for explaining the timing and the magnitude of the decline in lending were tested and found to be consistent with the data to varying degrees. These include: implementation of tougher capital standards - risk-based or leveragebased, explicit or implicit (e.g., Berger and Udell 1994, Hancock and Wilcox 1994, Peek and Rosengren 1995b, Hancock, Laing, and Wilcox 1995, Shrieves and Dahl 1995, Wagster 1999, Furfine 2001); an increase in supervisory toughness, such as worse CAMELS ratings, higher classified assets, more formal actions for a given portfolio (e.g., Peek and Rosengren 1995a, Berger, Kyle, and Scalise 2001, Furfine 2001); bank retrenchment or reduced risk taking due to portfolio risks, losses, impaired capital, changed risk tolerance, etc. (e.g., Hancock and Wilcox 1994, 1998, Berger and Udell 1994, Peek and Rosengren 1995b, Wagster 1999, Furfine 2001); or reduced loan demand (e.g., Bernanke and Lown 1991, Berger and Udell 1994, Furfine 2001).

The research on the credit crunch provides only a partial explanation of the stylized facts about procyclicality because it neglects bank behavior during the expansion of the business cycle and any linkage between bank behavior in the expansion and bank performance in the downturn. A credit crunch is a reduction in supply that is measured against a control period of "normal" credit supply, or supply during an economic expansion. If there is a significant easing of credit standards during an aggregate expansion - as would be 
consistent with the stylized facts - then a credit crunch during the downturn may be the result, at least in part, of lower quality loans issued during the expansion that created problem loans and depleted capital ratios that become apparent later in the cycle. That is, the seeds of the credit crunch may be sown at the top of the cycle.

Some recent research has examined the expansionary part of the business cycle to try to explain some of the stylized facts. One explanation is over-optimism. During the expansion, banks may underestimate their risk exposure and ease their credit standards, which increases the magnitude of losses when the next downturn ffcurs. This type of behavior may be consistent with recent theories of behavioral finance or bounded rationality. ${ }^{6}$ Bank lending behavior might be based on euphoric expectations associated with an investment boom driven by the business cycle (Minsky 1977) or on "disaster myopia" where the subjective probability of a major shock increases as time elapses since the last shock (Guttentag and Herring 1984). The paucity of data available to bank managers across business cycles may also be a contributing factor, making it particularly difficylt for them to assess the systematic component of risk in their portfolios (e.g., Borio, Furfine, and Lowe 2001). ${ }^{7}$

Reduced supervisory toughness or lessened market discipline during an expansion offers another explanation of a decline in credit standards. Bank supervisors were found to soften their loan classification standards and their CAMELS ratings during an expansion (Berger, Kyle, and Scalise 2001), and capital market participants were found to exercise less discipline over issues of subordinated debt during relatively good periods (Covitz, Hancock, and Kwast 2000). As discussed above, the reduced discipline could come about because agency problems are exacerbated by the lack of data on loan performance problems during an expansion. Some are also concerned that the new Basle capital regulations could introduce more procyclicality in lending to the extent that banks adopt the internal ratings-based (IRB) approach. This could occur because individual borrower ratings may depend on assessed probability of default, which may be correlated with the business cycle (Altman and Saunders 2001, Zsamboki 2002).

Herding behavior may also be a factor in explaining the stylized facts. Because of the agency problem between bank managers and outside owners, managers of different banks may ease credit standards simultaneously during an expansion to mask emerging problems, then tighten standards only when the condition

\footnotetext{
${ }^{6}$ This is analogous to investors becoming over-optimistic about recent winners and over-pessimistic about recent losers (De Bondt and Thaler 1995).

${ }^{7}$ One recent paper found that commercial real estate lending follows a "trend-chasing" pattern in which investment is at its highest when ex ante returns are at their lowest, consistent with over-optimism (Mei and Saunders 1997).
} 
of the borrowing sector has deteriorated considerably (Rajan 1994). ${ }^{8}$ Similarly, banks may herd because penalties imposed by government supervisors may be perceived to be lighter if many banks are troubled simultaneously (Acharya 2001) or because of contagion effects across institutions (Acharya and Yorulmazer 2002).

One potential explanation for the second stylized fact - that observed loan performance problems are minimal until the end of an expansion, then rise dramatically during the downturn - is loan seasoning. Loan seasoning refers to the phenomenon that loan performance problems - such as past due, nonaccrual, provisions, and charge-offs - are ex post measures of bank risk taking that generally materialize only with a lag. During an expansion, more new loans are issued, making the stock of loans relatively young and less likely to have observed performance problems (e.g., Avery and Gordy 1995). During a downturn, fewer loans are issued, so the average loan age increases and more problem loans are observed.

The institutional memory hypothesis may interact with other procyclicality hypotheses. That is, the institutional memory theory does not rule out the other theories - they may be complementary. The institutional memory problem may be exacerbated by the credit crunch hypotheses, over-optimism, reductions in supervisory toughness/market discipline, herding, and/or loan seasoning. For example, over-optimism may encourage loan officers to ease their credit standards further, causing inexperienced loan officers to lend even more, and further clouding the memories of the experienced loan officers. Similarly, loan seasoning that delays the observation of problem loans may add further to the lags with which 1) junior loan offices gain experience with problem loans, 2) senior loan officers restore their memory about problem loans, and 3) bank management and outside stakeholders obtain sufficient feedback to evaluate lending behavior.

The economic significance of procyclicality in the lending cycle driven by the institutional memory hypothesis - or driven by any other source - depends largely on the extent to which this procyclicality affects the business cycle and aggregate output. Empirical evidence on the two credit channels of monetary policy transmission suggests that bank lending is important to the aggregate economy. Research on the "bank lending view" credit channel shows that monetary policy significantly affects the supply of bank loans through its impact

\footnotetext{
${ }^{8}$ Herding in a lending model may involve an information cascade in which the initial actions of some agents cause others to ignore their own private information and make negative NPV loans (Banerjee 1992, Welch 1992). This type of model would typically result in a rapid shift away from this overlending once they learn that their lending activities are problematic. However, in one model of procyclicality in which ability is valued more during a boom than in a bust, herding behavior persists until late in the boom (Rajan 1994). In this model, lending is exceptionally expansionary during the boom but normal during the bust.
} 
on bank reserves; and this, in turn, significantly affects the macroeconomy (see Kashyap and Stein 1997 for a survey). Research on the "balance sheet" credit channel indicates that monetary policy affects lending and the macroeconomy significantly through changes in interest rates that affect the creditworthiness of borrowers by altering the quality of their balance sheets and collateral (see Bernanke and Gertler 1995, Bernanke, Gertler, and Gilchrist 1996 for summaries).

Evidence from the credit crunch literature suggests that factors such as changes in bank capital that suppressed bank lending also had an effect on the real economy (Hancock and Wilcox 1998). More closely related to the institutional memory hypothesis, there is evidence that changes in credit standards may be linked to the macroeconomy. One study using a VAR methodology found that shocks to lending standards as measured using the Senior Loan Officer Survey (SLOS) significantly affected both commercial loan volume and real output (Lown and Morgan 2002). A study that used credit terms instead of the SLOS survey data similarly found a link between credit standards and aggregate economic performance. This study found that loan rate premiums were lower during economic expansions and higher during downturns, and that this was linked to the level of unemployment over the business cycle (Asea and Blomberg 1998).

\section{Empirical model, variables, and data sets}

In this section, we first briefly outline the empirical model employed to test the institutional memory hypothesis. We then describe the variables and data sets employed in the tests.

\subsection{Empirical model}

The main testable prediction of the institutional memory hypothesis is that credit standards ease as time passes since the bank's last bust due to the deterioration in the skill level of loan officers, which is exacerbated by the worsening of agency problems between loan officers and bank management and between bank management and outside stakeholders. The basic empirical model employed in the tests is given by:

Indicator of bank's credit standards $\mathrm{b}_{\mathrm{b}, \mathrm{t}}=f$ (time since bank's last bust ${ }_{\mathrm{b}, \mathrm{t}}$, control variables $\mathrm{b}_{\mathrm{b}, \mathrm{t}-1}$ ),

where the dependent variable is an indicator of bank b's credit standards at time t, the key exogenous variable is the number of years since bank b's last bust, and the control variables account for other factors affecting the demand for and supply of bank b's credit. Equation (1) is a reduced form equation that takes both demand and supply factors into account, although our attention is primarily focused on one supply factor - the time since the 
bank's last bust.

We test the institutional memory hypothesis using the bank's commercial loan growth as the main indicator of its credit standards. As discussed further below, we also run equation (1) using the premiums over risk-free rates charged on its commercial loans, and its responses to the Senior Loan Officer Survey regarding its credit standards and spreads of its loan rates over its cost of funds. The key exogenous variable is measured as the number of years since the bank's portfolio was in its worst condition over an interval that includes the current year and the prior 10 years, i.e., the time since its worst condition over the interval $[t-10, t]$. The control variables are discussed below.

The model is estimated using data from individual U.S. banks from 1980-2000 - approximately two full business cycles (although the full period is not available for the Senior Loan Officer Survey tests). The data sets also include information back to 1970 to construct the "time since" exogenous variables, which are based on the last bust over the $[\mathrm{t}-10, \mathrm{t}]$ time interval. For an observation to be included in the data set, the bank must have a history of 10 consecutive prior years of performance to construct a sufficient "time since" history. For the discarded observations, it would be difficult to determine the time since their last bust and it is not clear how well the institutional memory hypothesis would apply (i.e., they have not had much time to "forget").

For completeness and to check robustness, we also run the model separately for several subsets of the data. We run the tests separately for the cycles of the 1980s (1980-1989) and 1990s (1990-2000) to examine how the results apply to these two cycles. There are reasons to believe that the 1990s are different - tougher capital standards, recovery from a significant credit crunch, technological change, etc. We also report the results for the 1986-2000 subsample because of a slight change in the definition of one of the variables (discussed below). Where possible, the tests are also run by bank size classes to investigate the extent to which the hypothesis applies to large versus small banks and by loan size class to determine the extent to which the hypothesis applies to loans to large versus small borrowers. We also run the regressions with only non-merging banks - i.e., deleting observations on banks that engaged in mergers over the $[\mathrm{t}-10, \mathrm{t}]$ time interval - to insure that our results are not due to mergers.

Descriptions and summary statistics for all of the variables employed in the analysis are shown in Table 1. Sample means are also shown for the three different data sets - the Call Report (CALL), Survey of Terms of Bank Lending (STBL), and Senior Loan Officer Survey (SLOS) data sets. Note that CALL and SLOS data are 
used in calculating some of the exogenous variables for all of the tests, but we divide up the tests and data sets by the dependent variables. All financial values are expressed in real 1994 dollars using the GDP deflator.

\subsection{Dependent variables and their corresponding data sets}

Our main indicators of credit standards are based on loan growth for each bank for each year taken from the CALL data set. We measure the annual proportional change in lending (i.e., $\left.\left(\mathrm{L}_{b, t}-\mathrm{L}_{b, t-1}\right) / \mathrm{L}_{\mathrm{b}, \mathrm{t}-1}\right)$ for commercial and industrial loans and commercial real estate loans, $\triangle$ LOANS-C\&I and $\triangle$ LOANS-CRE. In both cases, the loan growth is merger-adjusted, so that any change in lending due to the effects of adding two or more balance sheets together through mergers is removed. We also delete the top and bottom $1 \%$ of the observations of $\triangle$ LOANS-C \&I and $\triangle$ LOANS-CRE. These extreme values - such as banks that increase their lending by several thousand percent in a single year or reduce lending to close to zero - likely reflect either data errors or idiosyncratic events that are unrelated to the institutional memory hypothesis. As shown in Table 1, the sample mean annual growth rates for C\&I and CRE loans (after trimming off the extreme values) are $6.52 \%$ and $11.00 \%$, respectively. Although the institutional memory hypothesis may apply to any category of lending, the effects are likely to be strongest for these commercial loan categories, in which loan officer judgment is of primary importance. As discussed below, we also try robustness checks using other types of bank loans.

The loan growth data are annual, and are available for the full sample period from $1980-2000$. The 21 years of data provide 203,243 bank-year observations that are employed in the loan growth regressions after trimming the top and bottom 1 percentage points of the dependent variables. ${ }^{9}$ The $\Delta$ LOANS-C\&I and $\Delta$ LOANSCRE regressions are run by OLS.

The institutional memory hypothesis predicts a greater flow of new lending as time passes since the bank's last bust, after controlling for other demand and supply factors. As time passes and the human capital of the loan officers deteriorates and credit standards decline, the loan officers may approve loans that they otherwise would have rejected earlier in the cycle and may raise the credit limits on other borrowers that would have received credit because the loan officers are less able to assess loan quality.

The loan growth tests using $\triangle$ LOANS-C\&I and $\triangle$ LOANS-CRE are relatively straightforward tests of the institutional memory hypothesis, as an increase in lending corresponds quite closely with the concept of an easing

\footnotetext{
${ }^{9}$ The CALL frequency is quarterly, but we prefer to use the annual data because the December CALL is generally considered to be the most accurate and because it smoothes out seasonal and other short-term fluctuations in lending.
} 
of lending standards. A significant increase in lending is also a necessary condition for the institutional memory hypothesis to help explain the stylized fact that bank lending tends to increase significantly during a business cycle expansion and fall significantly during a downturn. However, we acknowledge that the change in the stock of loans is an imprecise measure of the flow of new loans, because the change in the stock also varies with loan maturity, prepayments, defaults, etc.

We also test the effects of the time since the bank's last bust on other indicators of credit standards. First, we use the premiums over risk-free rates charged on its loans taken from the Federal Reserve's Survey of Terms of Bank Lending (STBL) as an indicator of credit standards. The STBL covers approximately 300 U.S. banks per quarter (although the respondent set is not constant over time), obtaining contract terms on all of their new domestic C\&I loans during one or more days of the first week of the second month of the quarter. The survey queries almost all of the largest banks in terms of C\&I lending plus a stratified random sample of smaller banks.

For each loan, we measure the loan rate premium over the risk-free rate of comparable duration, i.e., the appropriate U.S. Treasury rate. For loan i made by bank b at time $t$ with duration $d$, we measure PREM $_{\mathrm{i}, \mathrm{b}, \mathrm{t}, \mathrm{d}} \equiv$ $r_{i, b, t, d}-r_{U S, t, d}$ as our dependent variable. The data are for individual loans from $1980-2000$. The 21 years of data provide 2,296,906 observations on individual loan contracts. As shown in Table 1, the average loan premium is $3.89 \%$ - i.e., the average loan has rate of 389 basis points above the risk-free rate. The $\mathrm{PREM}_{\mathrm{i}, \mathrm{b}, \mathrm{t}, \mathrm{d}}$ regressions are run by OLS.

We test whether loan premiums decline as time passes since the bank's last bust, controlling for other factors affecting demand and supply. The institutional memory hypothesis predicts that loan officers become less able to recognize potential loan problems and to differentiate lower-quality borrowers from higher-quality borrowers later in the bank's cycle. As a result, the bank may charge low premiums for some relatively risky loans. For example, as credit standards ease, loan officers may put some unobservable "prime +3 " borrowers into the "prime +2 " risk pool, reducing PREM.

Despite this prediction of the hypothesis, PREM may not decline even if the institutional memory hypothesis is true. Bank management may keep rates from falling or even impose higher rates as time passes since the bank's last bust as one of the blunt instruments for addressing institutional memory problems. As discussed in section 2, management could impose higher rates on observable classes of loans to compensate for the unobserved lower quality credits that are likely to be included in these classes. Put another way, the bank may raise rates to 
account for the inclusion of unobservable lower-quality credits in higher-quality risk pools. ${ }^{10}$ Thus, the PREM tests are not direct tests of the institutional memory hypothesis, but they may be informative about its effects. Given the potential offsetting effects, if we were to find that PREM declines as time passes since the bank's last bust, we would view this as evidence consistent with the institutional memory hypothesis. However, a finding of no effect is ambiguous - it may reflect that the hypothesis is not true or it may reflect that the hypothesis is true but that the pricing effects are offset by management.

Our third set of indicators of credit standards are taken from responses to the Federal Reserve's Senior Loan Officer Opinion Survey on Bank Lending Practices (SLOS). The SLOS has asked a consistent set of questions about the credit standards of about 60 large commercial banks from around the U.S. since 1990:Q3. These large banks account for over half of all domestic C\&I lending (e.g., the 61 SLOS banks in 2000 made $54.22 \%$ of all domestic C\&I lending). Some studies have shown empirically that the SLOS is an informative measure of changes in credit standards because it helps predict future lending and changes in aggregate U.S. output (Lown, Morgan, and Rohatgi 2000, Lown and Morgan 2002). ${ }^{11}$

The SLOS asks senior bank loan officers whether over the prior three months the bank's credit standards on commercial and industrial (C\&I) loans and credit lines (other than those used to finance mergers and acquisitions) 1) tightened considerably, 2) tightened somewhat, 3) remained basically unchanged, 4) eased somewhat, or 5) eased considerably (although no bank reported considerable easing). As shown in Table 1, we combine the two tightening categories and reverse the order to obtain a quarterly trinomial variable for each bank, STANDARDS $\mathrm{b}_{\mathrm{b}, \mathrm{t}}$, which equals 1 if bank $\mathrm{b}$ reports that it eased its credit standards in quarter $\mathrm{t}, 2$ if standards remained basically unchanged, and 3 if standards were tightened. ${ }^{12}$

In addition, the SLOS asks about the spreads charged on these C\&I loans and lines over their cost of funds. We again combine the categories and obtain a quarterly trinomial variable for each bank, SPREADS $\mathrm{S}_{\mathrm{b}, \mathrm{t}}$

\footnotetext{
${ }^{10}$ The effect of the institutional memory hypothesis in reducing PREM may also be moderated, although not reversed, by banks imposing "sticky" loan pricing policies in which loan rates do not vary much with aggregate interest rates or credit conditions (e.g., Stiglitz and Weiss 1981, King 1986, Berger and Udell 1992, Petersen and Rajan 1995, Berlin and Mester 1999).

${ }^{11}$ Research based on an earlier version of the SLOS questions (not employed here) suggested that there may have been a bias against revealing to bank supervisors that credit standards had eased (Schreft and Owens 1991). Such a bias, if it exists in our data set, would reduce but not necessarily eliminate the informativeness of the data.

${ }^{12}$ The credit standards are collected separately for credits to large and middle-market firms (annual sales of $\$ 50$ million or more) and small firms (sales of less than $\$ 50$ million). Since the responses are almost always the same (about $98 \%$ of the time), we simply use the responses for the credits to the former group.
} 
which equals 1 if bank b reports that it narrowed its spreads (eased its pricing standards) in quarter t, 2 if spreads remained basically unchanged, and 3 if standards were widened (standards were tightened).

The STANDARDS and SPREADS variables are available quarterly from 1990:Q3 - 2000:Q4, and cover approximately one business cycle, rather than the approximately two cycles of the CALL and STBL data sets. The 42 quarters of data provide 2,338 bank-quarter observations, or an average of 55.67 banks per quarter. The SLOS sample also represents only large banks. Of these observations, 1,602 (68.52\%) have assets over $\$ 10$ billion, $734(31.39 \%)$ have assets between $\$ 1$ billion and $\$ 10$ billion, and only $2(0.09 \%)$ have assets between \$100 million and \$1 billion.

The sample mean of STANDARDS is 2.0453, with banks having reported easing credit standards slightly less often $(5.30 \%$ of the time) than they reported tightening (9.84\%), although the majority of the time (84.86\%) the banks reported no change in standards. The sample mean of SPREADS is 1.9196, with banks having reported easing or narrowing spreads slightly more often $(26.43 \%$ of the time) than they reported easing or widening the spreads $(18.39 \%)$, with no basic change in spreads most of the time $(55.18 \%)$.

The institutional memory hypothesis yields a prediction that individual loan officers ease their credit standards as time passes since the bank's last bust, but no direct prediction about intentional easing or tightening by the senior management of the bank to whom the questions are addressed. It is nonetheless informative to learn whether senior management acknowledges the changes in credit standards by its loan officers if the hypothesis is true. As discussed above, senior management may attempt to offset part of the easing of loan officer standards by imposing blunt policy instruments like higher premiums, tighter credit limits, or increased collateral requirements on observed classes of loans to compensate for the unobserved lower-quality credits that may be included in these classes. This tightening could influence the responses to the STANDARDS and SPREADS questions.

\subsection{The key exogenous variable - Time since the bank's last bust}

Our key exogenous variable - time since the bank's last bust - is defined as the number of years since the bank's portfolio was in its worst condition over the interval $[\mathrm{t}-10, \mathrm{t}]$, and may take values between 0 and 10 , inclusive. This interval is longer than the longest aggregate expansion in the data set, giving enough time for most banks to have had at least one "learning experience." Experiences that occurred more than 10 years prior are less likely to be relevant to the current set of loan officers.

As our main measure, we use TIME-ALLL ${ }_{b, t}$, years since the ratio of the allowance for loan and lease 
losses to total loans (ALLL) was at its maximum over the $[\mathrm{t}-10, \mathrm{t}]$ time interval. For the CALL and STBL data sets, which cover the full 1980-2000 time interval, TIME-ALLL $L_{b, t}$ has sample means of 4.9544 and 4.9800 years, respectively. For the SLOS sample, which only covers large banks over 1990:Q3 - 2000:Q4, the mean is 4.5522 years. There is also considerable dispersion in this variable both across time and across banks. For example, in the CALL data set, $17.80 \%$ of observations take the value 0 (i.e., this year is worse than any of the prior 10 years), $17.04 \%$ take the value 10 (i.e., this year and the prior 9 years are all better than 10 years ago), and nontrivial proportions take each value between 0 and 10 years (not shown in tables).

We use TIME-ALLL as our main measure of the time since the bank's last bust because ALLL is arguably the best indicator of the status of problems in the loan portfolio. ALLL is a measure of problem loans at any given time that takes into account the severity of the problems. The point in time at which ALLL is at its maximum over the period is likely to give the best opportunity for a "learning experience" in which loan officers can connect ex post outcomes with their ex ante decisions. Loan officers specifically learn from their problem loans about the association between firm characteristics and risk, the valuegf different deal structures, monitoring strategies and procedures, and strategies for managing distressed credits. ${ }^{13}$ Because of reporting changes on the CALL, we measure TIME-ALLL with a slightly different definition over the years 1980-1985, although robustness checks shqwn below using only observations from 1986-2000 suggest that this is not a determining factor in our findings. ${ }^{14}$

A potential shortcoming of TIME-ALLL is that ALLL captures only one dimension of a lending relationship's ex post outcome - expected future loan losses. Other dimensions of a problematic ex post outcome include the loss in profitability from other components of the bank-borrower relationship (e.g., fees on derivative

\footnotetext{
${ }^{13}$ ALLL is also monitored by supervisors to be sure that banks have enough reserves to cover expected losses from their existing loans. Banks are required to hold reserves equal to at least $1 \%$ to $2 \%$ for unclassified and special mention loans, $15 \%$ for substandard, $50 \%$ for doubtful, $100 \%$ for loss. Examiners check the loan portfolio and require that banks raise their ALLL when it is not sufficient.

${ }^{14}$ The CALL variable RIAD3123, allowance for loan and lease losses, is available on a consistent basis from 1976 through 2000 (except that leases are excluded prior to 1984), so this definition is used in the numerator of the ALLL measures to compute TIME-ALLL for the years 1986-2000. This variable cannot be used for construction for TIME-ALLL for 19801985 because of the need for 10 prior years of consistent data to determine the bank's last bust over the $[\mathrm{t}-10, \mathrm{t}]$ time interval. For 1970-1975, the closest variable is RIAD3120, reserve for bad debt losses on loans, which includes the allowance for loan losses plus other items. We come as close as possible to a consistent series that matches RIAD3120 over 1976-1983 by summing RIAD3123 with RIAD2936 and RIAD2937 (the latter two items measure deferred income taxes which are included in RIAD3120 for 1970-1975). For 1984 and 1985, RIAD2936 and RIAD2937 are not available, so we use the 1983 values for the same bank. These data manipulations apply only to TIME-ALLL, which requires lagged variables prior to 1976, and do not affect the ALLL variable used in the regressions as a measure of bank health.
} 
products, cash management services, and capital markets products) and the increased costs of loan officer and senior management time and other expenses related to the management of deteriorating credits (e.g., conducting on-site field examinations of borrower books and records), etc. To address this potential shortcoming, we use as a robustness check TIME-ROE $\mathrm{b}_{\mathrm{t}, \mathrm{t}}$, years since the bank's return on equity was at its minimum over the [t-10,t] interval as an alternative measure. ROE captures the earnings losses from other components of the bank-borrower relationship and the increased costs of managing distressed credits, as well as the current provisions to ALLL. A drawback of ROE is that it also includes earnings that are unrelated to the loan portfolio.

\subsection{The control variables}

The control variables include measures of bank health, bank size and market concentration, and loan demand. For some of the loan premium regressions, we also include controls for other loan contract terms. In all cases, we include fixed effects for the individual banks, which account for average differences across banks not captured by the other exogenous variables. The bank fixed effects reduce correlations across error terms as well.

We also run the tests both with and without time fixed effects. As noted, time fixed effects make for quite stringent tests of the institutional memory hypothesis, by in effect removing the part of the bank's lending cycle that is correlated with the aggregate business cycle. The time fixed effects also in effect control for the other hypotheses of procyclicality - the credit crunch theories, theories of over-optimism, changes in supervisory toughness, herding, and loan seasoning - to the extent that these other hypotheses are driven by or correlated with the aggregate business cycle or other overall economic conditions. As well, the time fixed effects reduce serial correlations in the error terms.

The t-1 subscript on the control variables in equation (1) denotes that these variables are measured as of the prior period to minimize any unintentional feedback from the endogenous variables, and to ensure that the credit standards being measured in the dependent variables did not occur prior to the exogenous control variables. One exception discussed below is that the loan contract terms that are sometimes included are for the same loan at the same time. Most of the control variables are taken from the CALL and matched to the dependent variables for appropriate data set, although the STBL and SLOS also provide some controls.

The bank health variables include both $\mathrm{ALLL}_{\mathrm{b}, \mathrm{t}-1}$ and $\mathrm{ROE}_{\mathrm{b}, \mathrm{t}-1}$, the levels of allocations for loan and lease losses and return on equity, as well as EQUITY/GTA $A_{b, t-1}$, the bank's ratio of equity to gross total assets (GTA). Bank health is included because prior research has demonstrated that banks in poor financial condition reduce 
credit supply due to pressure from regulators and supervisors and other external stakeholders, as well as internal pressure to rebuild capital and avoid financial distress.

For bank size, we include the log of gross total assets, $L N(G T A)_{b, t-1}$ because banks may compete in somewhat different loan markets with different conditions as they change in size. We also include the weighted average Herfindahl index of market concentration across all the markets in which the bank competes, HERFINDAHL $_{\mathrm{b}, \mathrm{t}-1}$, to account for differences in market power.

It is particularly important to control for loan demand, both in terms of loan applicants of a given risk demanding more or less credit, and in terms of applicants becoming riskier or safer, since a riskier borrower will be granted less credit or pay a higher PREM $\mathrm{b}_{\mathrm{b}, \mathrm{-}}$ even if there is no change in loan supply. We include state and national income growth, ST-GROW $\mathrm{b}, \mathrm{t}-1$ and GDP-GROW $\mathrm{b,t-1}$, as higher income growth is likely to be associated with improved investment opportunities and greater demand for credit for a given risk and with reduced risk. The spread between Moody's BAA and AAA long-term bonds, MOODY $\mathrm{b}, \mathrm{t}-1_{1}$, is an indicator of aggregate risk. The three-month Treasury rate, $\mathrm{RF} 3 \mathrm{MO}_{\mathrm{b}, \mathrm{t}-1}$, affects the demand for credit in conventional terms, and also may affect borrower risk through moral hazard and adverse selection effects (e.g., Stiglitz and Weiss 1981). When we include time fixed effects, we exclude the national demand variables GDP-GROW, MOODY, RF3MO, since these are collinear with the time dummies.

For the SLOS data set, we also control for a measure of demand specific to the bank. Beginning in 1992:Q1, the SLOS asks whether the perceived demand for C\&I loans over the prior over the prior three months was 1) substantially stronger, ...,5) substantially weaker. We use the responses to form three control variables, SLOS-Own Demandj $\mathrm{j}_{\mathrm{b}, \mathrm{t}-1}$, where $\mathrm{j}=1,2,3$ correspond to weaker, unchanged, and stronger demand, respectively, over the prior quarter, with SLOS-Own Demand1 excluded from the SLOS regressions as the base case. In some cases, the Own Demand variables are missing from the SLOS data set because the observation occurs during 1990:Q3 - 1991:Q4 (before the Own Demand series began) or because the bank answered about its STANDARDS and SPREADS but did not respond to the Own Demand question. We indicate these cases with the SLOS-Missing Own Demand variable and set the other SLOS-Own Demand variables to zero.

For the CALL, STBL, and SLOS data sets we also form three control variables for aggregate loan demand changing from the prior year, SLOS-Aggregate Demand $\mathrm{j}_{\mathrm{t}-1}, \mathrm{j}=1,2,3$, in ascending order from weaker to stronger demand (again excluding the first variable for weak demand from the regressions as the base case). These 
variables represent the proportions of banks facing on average stronger, similar, or weaker demand over the four prior quarters, starting with the first quarter of the current year. These SLOS demand variables are set equal to zero for observations prior to 1992, when there was no information available on demand from the SLOS. To neutralize the average effect of these missing observations, we also include in all the regressions the SLOSMissing Agg. Demand dummy, which equals 1 for all of the observations with no SLOS aggregate demand variables. ${ }^{15}$ As above, when we include time fixed effects, we exclude all the SLOS aggregate demand variables as collinear with the year dummies.

As additional control variables in the PREM regressions only, we include other loan contract terms for whether collateral is pledged, whether the loan is a draw under a commitment, the duration of the loan, whether the rate is floating, and the total size of the credit (including the entire commitment, if any), COLLATERAL $\mathrm{i}_{\mathrm{i}, \mathrm{b}, \mathrm{t}}$, COMMITMENT $_{\mathrm{i}, \mathrm{b}, \mathrm{t}}$, DURATION $_{\mathrm{i}, \mathrm{b}, \mathrm{t}}$, FLOATING RATE $_{\mathrm{i}, \mathrm{b}, \mathrm{t}}$, and TOTAL CREDIT SIZE $\mathrm{i}, \mathrm{b}, \mathrm{t}$, respectively, for loan $\mathrm{i}$ issued by bank $\mathrm{b}$ at time $\mathrm{t}$. These other terms help control for the risks, costs, borrower type, etc. However, to some extent, these terms are also endogenous and may change with the credit standards of the bank, so we run the PREM regressions with and without these controls.

\section{Empirical results}

\subsection{Loan growth test results}

Table 2 displays the results of the direct tests of the institutional memory hypothesis employing loan growth, $\triangle$ LOANS-C\&I and $\triangle$ LOANS-CRE, to indicate bank credit standards using the CALL data set for the full sample from 1980-2000. The first two columns display the tests including both the bank and time fixed effects, and the last two columns show these tests with the bank fixed effects only. The control variables are identical except that the aggregate loan demand variables that do not vary in the cross section are excluded when the time fixed effects are included to avoid perfect collinearity.

The coefficients on the TIME-ALLL variable are positive and statistically significant at the $1 \%$ level in all four cases in Table 2, consistent with the implication of the institutional memory hypothesis that credit standards ease and more loans are issued as time passes since a bank's last bust. These figures of between 0.0024 and 0.0058 are economically significant as well as statistically significant. For example, the coefficient of 0.0053

\footnotetext{
${ }^{15}$ Similar to the credit standards, the demand variables are collected separately for credits to large and middle-market firms and small firms, and we simply use the responses for the former group.
} 
predicts that for an additional year since a bank's ALLL was at a maximum over the $[\mathrm{t}-10, \mathrm{t}]$ interval, its domestic C\&I loan growth would be 0.53 percentage points higher. Thus, after 5 years of a sustained boom approximately the sample average of TIME-ALLL - the expected annual loan growth would be 2.65 percentage points higher, which is economically significant relative to the mean value for $\triangle$ LOANS-C\&I of $6.52 \%$.

As shown in Table 3, we rerun the regressions for a number of different subsamples of the data. The table shows only the estimated coefficients and $t$ statistics for the key exogenous variable TIME-ALLL, but the same control variables are included. The test results are robust across all of the subsamples. As shown, the loan growth results are statistically and economically significant for the three time subsamples. The 1980-1989 and 1990-2000 subsamples roughly correspond to the two aggregate business cycles covered by our data set, and the 1986-2000 subperiod avoids the slight change in definition of TIME-ALLL due to reporting changes on the Call Report, as discussed above. These data suggest that the institutional memory hypothesis holds for both business cycles and that our test findings were not driven by the slight change in variable definition.

Table 3 also shows the test results when the model is rerun for each of four bank size classes separately, gross total assets (GTA) under $\$ 100$ million, $\$ 100$ million to $\$ 1$ billion, $\$ 1$ billion to $\$ 10$ billion, and over $\$ 10$ billion. As discussed above, the institutional memory hypothesis could apply with greater force to either small or large banks. Small banks tend to lend extend proportionately more relationship-based credit to informationally opaque borrowers for which institutional memory is relatively important. However, large banks tend to have greater separation of ownership and control and more layers of separation between management and loan officers than small banks, which may exacerbate institutional memory problems. As shown in Table 3, the test results are again robust - the coefficients of TIME-ALLL are statistically and economically significant for banks of all size classes for both C\&I and commercial real estate loan growth.

We also try trimming the CALL data set down to only banks in the STBL data set. As well, we try including only non-merging banks - banks that have not engaged in mergers over the entire $[\mathrm{t}-10, \mathrm{t}]$ time interval. Neither of these sample selection issues appears to matter - the results are statistically and economically significant for these subsamples as well.

The loan growth results were also robust with respect to a number of other changes in specification not shown in the tables. As noted above, the institutional memory hypothesis may apply to any category of lending, so we also tried alternative dependent variables, replacing $\triangle$ LOANS-C\&I and $\triangle$ LOANS-CRE with the growth of 
total loans, consumer loans, and other loans. We also tried alternative specifications of the key exogenous variable, replacing TIME-ALLL with the time since ROE was at its minimum over the $[t-10, t]$ interval and with the time since net loan loss provisions (the flow into ALLL) was at its maximum over the interval. In all of these cases, the results were statistically and economically significant.

For the most part, the control variables in the loan growth regressions shown in Table 2 have the expected signs and are statistically significant. As expected, healthier banks, larger banks, and banks in growing states tend to lend more, all else equal. Some of the aggregate demand variables have conflicting signs, but this may be due to putting in so many similar measures as well as including the bank fixed effects.

\subsection{Loan rate premium test results}

Table 4 shows the loan rate premium tests using the STBL data set for the full sample from 1980-2000. The regressions in the first two columns show the PREM tests results including both the bank and time fixed effects, and the last two columns show the tests with the bank fixed effects only. The regressions are also run twice, once with and once without the other loan contract terms as control variables because of potential endogeneity.

The coefficients on the TIME-ALLL are negative and statistically significant in three cases and positive and statistically significant in the fourth case, but none of these coefficients are economically different from zero. The coefficients of between -0.00005 and 0.00003 predict that for an additional year since the bank's ALLL were at a maximum over the $[t-10, t]$ interval, PREM would be between about 0.005 percentage points $(1 / 2$ of 1 basis point) lower and 0.003 percentage points ( $1 / 3$ of 1 basis point) higher. Thus, after 5 years of a sustained boom the expected PREM would be between 0.025 percentage points ( 2.5 basis points) lower and 0.015 percentage points (1.5 basis points) higher, which is not economically significant relative to the mean value for PREM of 3.89\% (389 basis points).

However, this finding of no economically significant effect of the time since the bank's last bust on PREM does not hold for all sizes of banks. Table 5 shows the PREM regressions for various subsamples. For the two smallest size classes (banks with GTA below \$1 billion), all eight coefficients on TIME-ALLL are statistically significant and negative, and most of the magnitudes are much larger than for the main results and for most of the other subsamples. For example, the coefficients of -0.00048 and -0.00050 for the smallest bank size class using the bank fixed effects only specification predict that for each additional year since the bank's ALLL were at a 
maximum over [t-10,t], PREM would be about 0.050 percentage points ( 5 basis points) lower. After 5 years of a sustained boom, the expected PREM would be about 0.250 percentage points ( 25 basis points) lower, which is economically significant. Again, the results in the PREM tests are robust to replacing TIME-ALLL with the times since ROE was at its minimum and net loan loss provisions were at their maximum over the $[\mathrm{t}-10, \mathrm{t}]$ interval.

In contrast, the finding of essentially a zero effect of the time since the bank's last bust on commercial loan prices holds for the large bank size classes (GTA above $\$ 1$ billion). This finding also holds for the time subsamples, holds for different credit size classes of loans (less than $\$ 100,000, \$ 100,000$ to $\$ 1$ million, over $\$ 1$ million), and holds for non-merging banks. Presumably, the findings for the full sample and the findings for these other subsamples are due to the fact that the banks in the large size classes dominate the data sets. As shown in Table 5, more than two million of the observed loan premiums are from banks with over $\$ 1$ billion in GTA, and less than 200,000 are from banks with under \$1 billion in GTA. Consistent with this presumption, when the time subsamples, credit size classes, and non-merging bank subsamples are re-run using data only for banks with GTA under $\$ 1$ billion, the measured effects are negative, larger in magnitude than for the full sample, and generally economically significant (not shown in tables).

As discussed above, the PREM tests are not direct tests of the institutional memory hypothesis, but they may nonetheless be informative. For small banks (below $\$ 1$ billion in GTA), the finding that PREM declines as time passes since the bank's last bust, particularly given the earlier results that loan growth also increased, is consistent with the institutional memory hypothesis. For large banks (above $\$ 1$ billion in GTA), the finding of no effect could reflect that the institutional memory hypothesis has no effect on loan pricing or could reflect that the pricing effects of the hypothesis are offset by managers that impose higher rates on observable risk classes to compensate for likely inclusion of lower quality credits.

\subsection{SLOS STANDARDS and SPREADS test results}

Table 6 shows the results of the STANDARDS and SPREADS tests using the SLOS data set, which primarily covers large banks during 1990-2000. These equations are run as ordered trinomial logit estimations eased, basically unchanged, or tightened for STANDARDS and narrowed, basically unchanged, and widened for SPREADS. The arrangement of the data is such that a negative coefficient on TIME-ALLL indicates easing standards or narrowing spreads as time passes since the bank's last bust. The first two columns show the STANDARDS tests results with and without the time fixed effects, and the last two columns show corresponding 
tests for the SPREADS variable.

None of the four coefficients on TIME-ALLL in Table 6 suggest that the management of the large institutions responding to the SLOS intentionally eased standards as time passed since the bank's last bust. Three of the four coefficients are not statistically significantly different from zero and the one that is statistically significant - SLOS SPREADS with bank fixed effects only - is positive, rather than negative. As discussed above, the institutional memory hypothesis is about the behavior of the individual loan officers, rather than the intentions of senior management. Given our finding above of a significant increase in commercial lending, the finding of no reported easing of standards or narrowing of spreads by senior management may imply that the change in standards is not intentional on the part of senior management or that the management is actively trying to offset the easing of standards, perhaps using one or more of the blunt policies described above.

\section{Conclusions}

Bank lending behavior appears to be highly procyclical. Lending tends to increase significantly during a business cycle expansion, and then fall considerably during a downturn, which likely accentuates the business cycle. Observed measures of loan performance problems also appear to follow a distinct pattern over the business cycle, staying at low levels until near the end of an economic expansion, and then rising dramatically during the subsequent downturn. The procyclicality of bank lending behavior may create a number of potential problems, including exacerbating the business cycle, increasing systemic risks, misallocating lending resources, and making it more difficult for external stakeholders (capital market participants and government regulators/supervisors) to discipline banks.

We offer and empirically test a new hypothesis that may explain in part why bank lending behavior follows this procyclical pattern. The institutional memory hypothesis is driven by deterioration in the skill level of bank loan officers over their bank's lending cycle. Under the hypothesis, as time passes since the last "learning experience" with problem loans - the last time that the bank suffered a loan "bust" - loan officer skills decline. Part of this decline in lender ability is attributable to a proportional increase in inexperienced lenders who have never had such a "learning experience." Part of the decline in lender ability is also due to the atrophying skills of experienced loan officers as time passes since they last addressed significant loan problems.

Under the hypothesis, the deterioration in loan officer skills results in an easing of credit standards and an increase in lending to lower-quality borrowers, as officers become less able to recognize potential loan problems 
and less able to differentiate lower-quality borrowers from higher-quality borrowers. The easing of standards may be compounded by the simultaneous deterioration in the capacity of bank management to discipline its loan officers and reduced capacities of external stakeholders (capital market participants, government regulators/supervisors) to discipline management because of the lack of observed loan performance problems. Further, it may be optimal for bank management and bank stakeholders to allow this to occur in equilibrium, because the imposition of blunt instruments involving raising prices or rationing credit may destroy bank-borrower relationships that might otherwise be very profitable over the long run. Although the institutional memory hypothesis is based on a bank's own loan performance problems, it nonetheless may help explain the stylized facts about the procyclicality of bank lending behavior over the aggregate business cycle because loan performance problems tend to be highly correlated across banks.

We test the institutional memory hypothesis using data from individual U.S. banks over the interval 19802000, drawing data from several different sources. The main testable prediction of the institutional memory hypothesis is that credit standards ease as time passes since the bank's last bust. Our key tests are based on commercial loan growth data from individual bank Call Reports, in which we test whether a bank's commercial and industrial lending and commercial real estate lending increase as time passes since the bank's last bust, controlling for other demand and supply factors. The last bust is measured as the point in time at which the ratio of the allowance for loan and lease losses to total loans was at its maximum over an interval that includes the current year and the prior 10 years. We find that the coefficient on this variable is positive, statistically significant, and economically significant for the growth of both types of commercial loans, providing strong evidence in support of the institutional memory hypothesis.

Running the tests for various subsamples of the data show that the main findings hold for the business cycles of both the 1980s and the 1990s, and also hold for all size classes of banks, ranging from less than $\$ 100$ million in assets to over $\$ 10$ billion in assets. Over both decades, and for institutions of all sizes, banks are found to increase their commercial loan growth as time passes since their last bust, controlling for other demand and supply factors. The findings are robust as well with respect to the exclusion of banks engaging in mergers, to the specification of additional loan categories, and to alternative specifications of the key exogenous variable.

Our main findings are also robust to the inclusion of both bank fixed effects and time fixed effects. The time fixed effects make the tests quite stringent because these effects control for the aggregate business cycle and 
other factors that change systematically over time. The time fixed effects also control for the effects of other hypotheses of procyclicality to the extent that these other hypotheses are driven by, or are correlated with, the aggregate cycle or other systematic factors.

The findings with regard to loan pricing, however, differ by size of bank. Using the Federal Reserve's Survey of Terms of Bank Lending, we find evidence that small banks (assets under \$1 billion) reduce their loan interest rate premiums by an economically significant magnitude as time passes since their last bust. Although this is not a direct test of the institutional memory hypothesis, it is nonetheless consistent with the hypothesis. The finding that premiums decline as loan growth increases for small banks is consistent with the implication of the hypothesis that the loan officers in these banks may be less able to recognize potential loan problems and place more lower-quality borrowers in higher-quality risk pools as time passes since their last bust.

Large banks, in contrast, exhibit essentially no change in loan premiums as time passes since their last bust. This finding could reflect that the institutional memory hypothesis does not significantly affect loan pricing for large banks or that the management of these banks may implement pricing policies to compensate for some of the pooling of unobserved lower-quality credits with higher-quality credits due to institutional memory problems. Consistent with this interpretation, we also find that large banks that responded to the Federal Reserve's Senior Loan Officer Opinion Survey showed no evidence that the senior management of these institutions intentionally eased standards or narrowed loan spreads as time passed since the bank's last bust. The difference in loan pricing results between large and small banks may also be due to the different types of credit issued by these banks, to the different organizational structures of these banks, or to other factors.

Thus, the evidence suggests that the loan officers of banks of all size classes ease their credit standards over their bank's lending cycle in terms of increased commercial loan growth in accordance with the institutional memory hypothesis. However, the senior management of large institutions may recognize this dynamic and compensate to some degree by imposing higher rates on observed risk classes of loans.

Overall, our findings suggest that institutional memory problems may significantly affect bank credit standards and the supply of commercial bank credit. These findings have several potential policy implications. They suggest the possibility that regulatory capital requirements and supervisory scrutiny might be more countercyclical than they otherwise would be to compensate for the unobserved changes in problem loans driven by institutional memory. Other theories of procyclicality that may operate concomitantly with the institutional 
memory hypothesis - such as over-optimism, loan seasoning, herding, and the credit crunch hypotheses - also emphasize the potential benefits from countercyclical regulatory and supervisory responses. Our findings suggest in addition that supervisors might act to counter an individual bank's lending cycle by becoming tougher when significant time has passed since the bank experienced its own last bout of performance problems.

Our findings may also suggest how bank managers and government supervisors might adjust the way they monitor bank loan portfolios. For example, banks might groom junior officers by exposing them to more loan work-outs early in their careers than they otherwise would to improve their learning experiences. As well, banks might allocate more seasoned officers than they otherwise would to loans that have not shown problems for a sustained period to look for more subtle indicators of future difficulties. Similarly, supervisors might expose junior examiners to banks with problem loans more than they otherwise would and assign more seasoned examiners than they otherwise would to banks that have not shown problems for a sustained period. 


\section{References}

Altman, E.I., Saunders A., 2001. An analysis and critique of the BIS proposal on capital adequacy and ratings, Journal of Banking and Finance, 25: 25-46.

Acharya, V.V., 2001. A theory of systemic risk and design of prudential bank regulation, London Business School working paper.

Acharya, V.V., Yorulmazer, T., 2002. Information contagion and inter-bank correlation in a theory of systemic risk, London Business School working paper, www.london.edu/faculty/vacharya/pdf/acharya-tanju.pdf

Asea, P.K., Blomberg, S.B., 1998, Lending cycles, Journal of Econometrics 83, 89-128.

Avery, R.B., Gordy, M., 1995. Loan growth, economic activity and bank performance. Federal Reserve Board working paper.

Beneish, D.M., 1999. The detection of earnings manipulation. Financial Analyst Journal: September/October, 24-36.

Bannerjee, A.V., 1992. A simple model of herd behavior, Quarterly Journal of Economics, 107, 797-818.

Berger, A.N., Kyle, M.K., Scalise, J.M., 2001. Did U.S. bank supervisors get tougher during the credit crunch? Did they get easier during the banking boom? Did it matter to bank lending? In F.S. Mishkin, ed., Prudential Supervision: What Works and What Doesn't, National Bureau of Economic Research, University of Chicago Press (Chicago, IL), 301-349.

Berger, A.N. Udell, G.F., 1992. Some evidence on the empirical significance of credit rationing, Journal of Political Economy 100, 1047-1077.

Berger, A.N., Udell, G.F., 1994. Did risk-based capital allocate bank credit and cause a 'credit crunch' in the United States? Journal of Money, Credit, and Banking 26 (August), 585-628.

Berlin, M., Mester, L., 1999, Deposits and relationship lending, Review of Financial Studies 12, 579-607.

Bernanke, B.S., Gertler, M., 1995, Inside the black box: The credit channel of monetary policy transmission, Journal of Economic Perspectives 9, 27-48.

Bernanke, B., Gertler, M., Gilchrist, S., 1996, The financial accelerator and the flight to quality, Review of Economics and Statistics 78, 1-15.

Bernanke, B.S., Lown, C., 1991. The credit crunch, Brookings Papers on Economic, 2 205-248.

Borio, C., Furfine, C., Lowe, P., 2001. Procyclicality of the financial system and financial stability: Issues and policy options, BIS working paper.

Borio, C., Lowe, P., 2002. Asset prices, financial and monetary stability: exploring the nexus, BIS working paper.

Butlin, M.W., Boyce, P.M., 1985. Monetary policy in depression and recovery, Australian National University Working Papers in Economic History No. 44.

Carey, M., Prowse, S, Rea, J., Udell, G., 1993. The Economics of the Private Placement Market, Financial Markets, 
Institutions \& Instruments 2.

Covitz, D.M., Hancock D., Kwast, M.L., 2000, Mandatory subordinated debt: Would banks face more market discipline?, Board of Governors of the Federal Reserve System, mimeo, December.

De Bondt, W., Thaler, R., 1985. Does the stock market overreact? Journal of Finance 40: 793-805.

Devenow, A., Welch, I., 1996. Rational herding in the financial markets, European Economic Review, 40, 603.-616.

Einarsson, T., Marquis, M.H., 2001. Bank intermediation over the business cycle. Journal of Money, Credit and Banking 33: 876-899.

Fisher, C. Kent, C., 1999. Two depressions, one banking collapse, Research Discussion Paper 1999-06, Reserve Bank of Australia, June.

Furfine, C., 2001. Bank portfolio allocation: The impact of capital requirements, regulatory monitoring, and economic conditions. Journal of Financial Services Research 20: 33-56.

Furth, D.L., 2001. Anticipating the next wave of bad loans: Function like a secondary market player. The Secured Lender (September/October), 31.

Gorton, G., Rosen, R., 1995. Corporate control, portfolio choice, and the decline of banking. Journal of Finance 50: 1377-1420.

Guttentag, J., Herring, R., 1984. Credit rationing and financial disorder. Journal of Finance 39: 1359-1382.

Hancock, D., Laing, A., Wilcox, J., 1995. Bank balance sheet shocks and aggregate shocks: Their dynamic effects on bank capital and lending, Journal of Banking and Finance, 19: 661-77.

Hancock, D., Wilcox, J.A., 1994. Bank capital and the credit crunch: The roles of risk-weighted and unweighted capital regulations. AREUEA, 22: 59-94.

Hancock, D., Wilcox, J.A., 1998. The 'credit crunch' and the availability of credit to small business, Journal of Banking and Finance 22, 983-1014.

Horvath, E., 2002, Lending booms, credit risk and the dynamic provisioning system, in Studies on the Procyclical Behaviour of Banks, National Bank of Hungary Occasional Papers \#10. http://www.mnb.hu/english/4_public/ocassional/opaper10.pdf.

Jordan, J., J. Peek, E. Rosengren, 2000. The market reaction to the disclosure of supervisory actions: Implications for bank transparency. Journal of Financial Intermediation 9, 298-319.

Kashyap, A.K Stein, J.C., 1997, The role of banks in monetary policy: A survey with implications for the European Monetary Union, Economic Perspectives, Federal Reserve Bank of Chicago, September/October, 3-18.

Kashyap, A.K., Stein, J.C., Wilcox, D.W., 1993. Monetary policy and credit conditions: Evidence from the composition of external finance. American Economic Review 83(1): 78-98.

Kerwin, R.J., 1994, Inventory fraud and the field examination. The Secured Lender, March/April: 24-32

King, S.R., 1986. Monetary transmission: Through bank loans or bank liabilities? Journal of Money, Credit and 
Banking 18, 290-303.

Lown, C.S., Morgan, D.P., Rohatgi, S., 2000. Listening to loan officers: The impact of commercial credit standards on lending output. Federal Reserve Bank of New York Economic Policy Review 6: 1-16.

Lown, C.S., Morgan, D.P., 2002. The credit cycle and the business cycle: New findings using the Senior Loan Officer Survey. Federal Reserve Bank of New York working paper.

Mei, J., Saunders, A., 1997, Have U.S. financial institutions' real estate investments exhibited 'trend-chasing' behavior? Review of Economics and Statistics, 79, 248-258.

Mero, K., 2002, Financial depth and procyclicality, in Studies on the Procyclical Behaviour of Banks, National Bank of Hungary Occasional Papers \#10. http://www.mnb.hu/english/4_public/ocassional/opaper10.pdf.

Minsky, H., 1977. A theory of systemic fragility. Financial Crisis, E. Altman and A. Sametz, eds., Wiley Interscience, New York.

Officer of the Comptroller of the Currency, Board of Governors of the Federal Reserve System, Federal Deposit Insurance Corporation, Office of Thrift Supervision, 2001, Leveraged Financing: Sound Risk Management Practices, Press Release, April 9. http://www.fdic.gov/news/news/press/2001/pr2801a.html.

Peek, J., Rosengren, E.S., 1995a. Bank regulation and the credit crunch, Journal of Banking and Finance, 19: 679-92.

Peek, J., Rosengren, E.S., 1995b. The capital crunch: Neither a borrower nor a lender be, Journal of Money, Credit and Banking, 27: 625-38.

Petersen, M., Rajan, R., 1995, The effect of credit market competition on lending relationships, Quarterly Journal of Economics 110, 407-443.

Rajan, R. 1994. Why bank credit policies fluctuate: A theory and some evidence. Quarterly Journal of Economics, $109,399-441$.

Schreft, S.L., Owens, R.E., 1991. Survey evidence of tighter credit conditions: What does it mean? Economic Review, Federal Reserve Bank of Richmond, March/April, 29-34.

Shrieves, R.E., Dahl, D., 1995. Regulation, recession, and bank lending behavior: The 1990 credit crunch, Journal of Financial Services Research, 9: 5-30.

Stein, J.C., 2002. Information Production and Capital Allocation: Decentralized vs. Hierarchical Firms, Journal of Finance, 57: 1891-1921.

Stiglitz, J., Weiss, A., 1981. Credit Rationing in Markets with Imperfect Information. American Economic Review, 71, 393-410.

Udell, G.F., 1989, Loan quality, commercial loan review and loan officer contracting, Journal of Banking and Finance 13, 367-382.

Udell, G.F., 2002, Asset Based Lending, Commercial Finance Association, New York, forthcoming.

Wagster, J.D. 1999. The Basle Accord of 1988 and the international credit crunch of 1989-1992, Journal of Financial Services Research, 15: 123-143. 
Welch, I., 2000. Herding among security analysts, Journal of Financial Economics, 58, 369-96.

Zsamboki, B., 2002, The effects of prudential regulation on banks' procyclical behaviour, in Studies on the Procyclical Behaviour of Banks, National Bank of Hungary Occasional Papers \#10. http://www.mnb.hu/english/4 public/ocassional/opaper10.pdf 


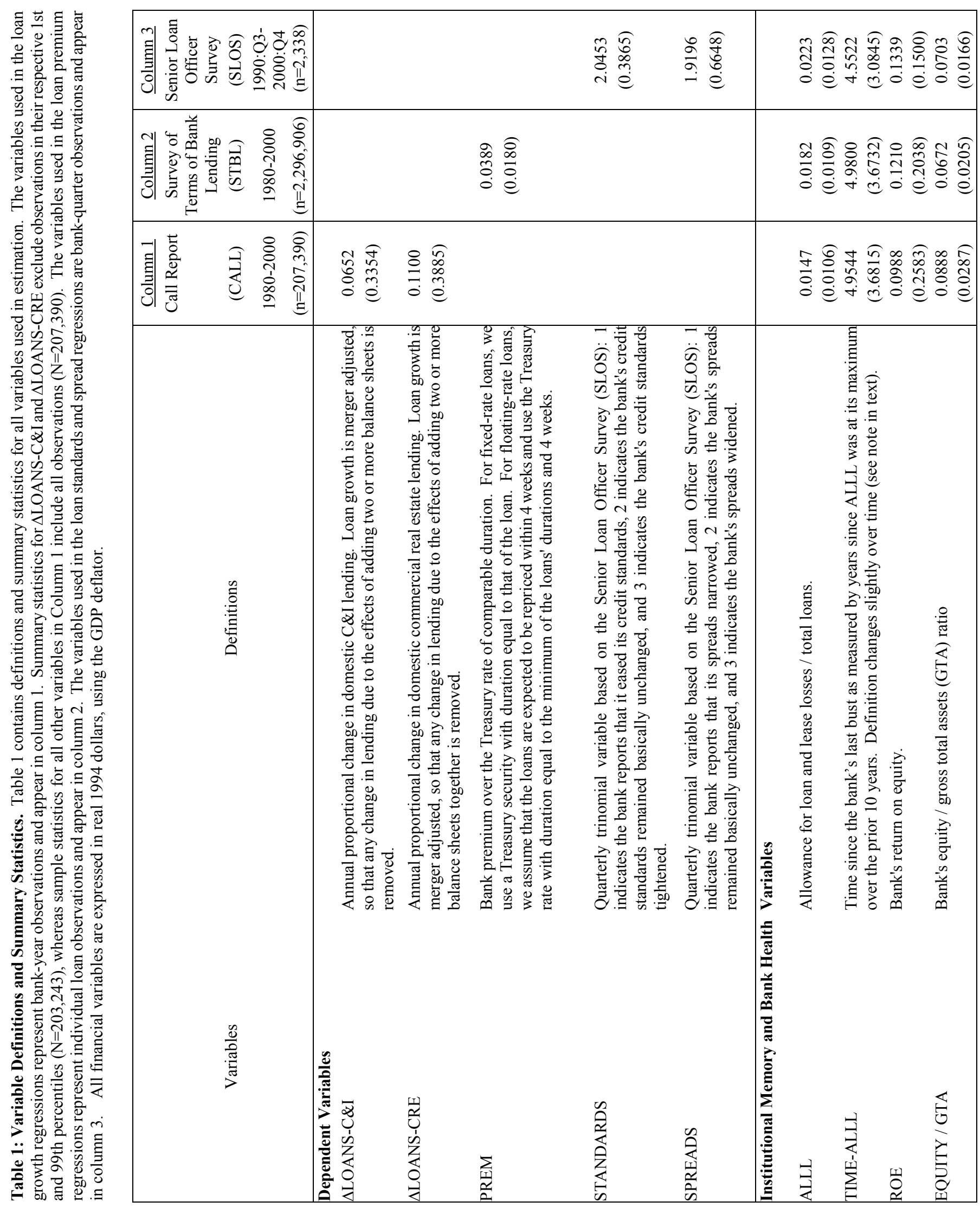




\begin{tabular}{|c|c|c|c|c|c|c|c|c|c|c|c|c|c|c|c|c|c|c|c|}
\hline 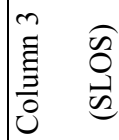 & & $\begin{array}{ll}\infty & \widehat{\bar{D}} \\
\stackrel{0}{=} & 0 \\
0 & \stackrel{0}{0}\end{array}$ & & $\begin{array}{l}\tilde{\delta} \\
\dot{0}\end{array}$ & $\begin{array}{l}\infty \\
\stackrel{0}{0} \\
\stackrel{0}{0}\end{array}$ & $\begin{array}{l}\infty \\
\infty \\
\check{\sigma} \\
\stackrel{\sigma}{+}\end{array}$ & $\begin{array}{l}\hat{\delta} \\
0 \\
0\end{array}$ & in & $\hat{r}$ & సે & $\infty$ & & $\begin{array}{l}\infty \\
\infty \\
\infty \\
\infty \\
\stackrel{\infty}{\infty} \\
0\end{array}$ & 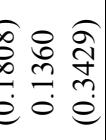 & & & & & \\
\hline 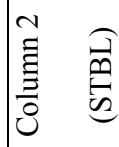 & & 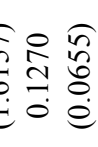 & & 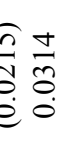 & $\underset{-}{\vec{\delta}}$ & \begin{tabular}{l}
$\vec{F}$ \\
$\infty$ \\
\multirow{0}{0}{} \\
$\delta$
\end{tabular} & & & & & 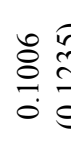 & సิ & 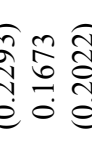 & 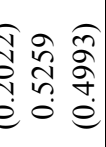 & & $n$ & $\approx$ & & 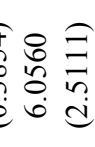 \\
\hline 音 & & 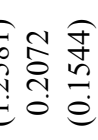 & & 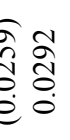 & 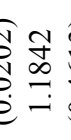 & पे & & & & & $\begin{array}{l}n \hat{2} \\
\hat{0} \\
0 \\
0\end{array}$ & 6 & $\begin{array}{l}\stackrel{a}{\circ} \\
=\frac{\infty}{0} \\
0\end{array}$ & 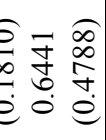 & & & & & \\
\hline 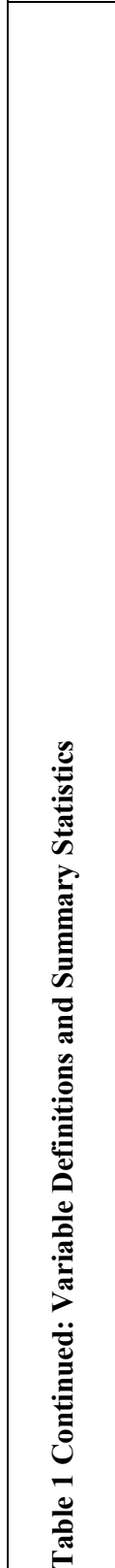 & 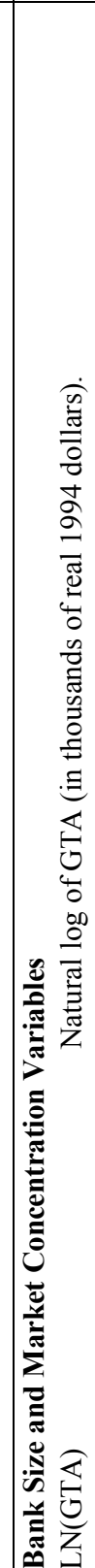 & 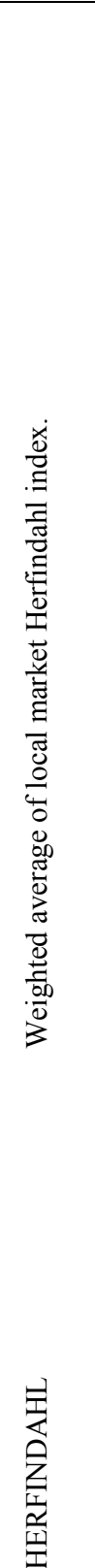 & 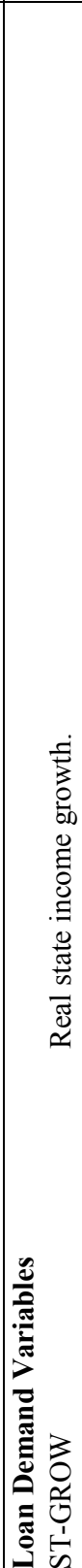 & 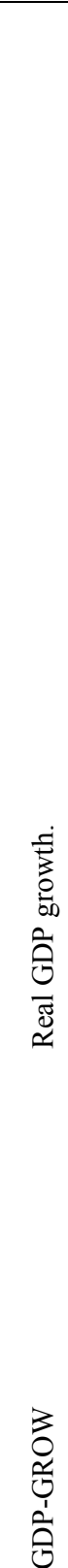 & 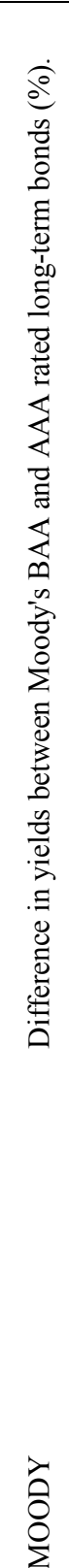 & 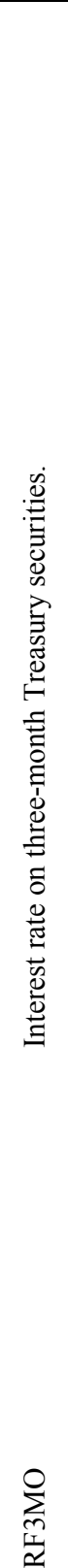 & 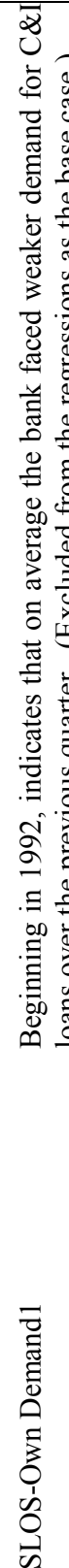 & 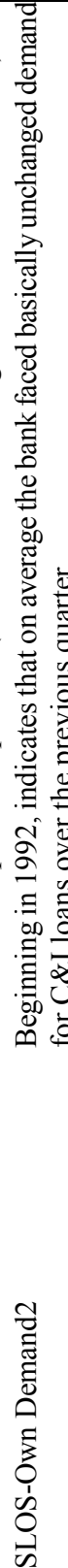 & 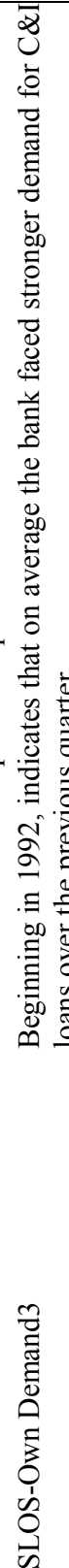 & 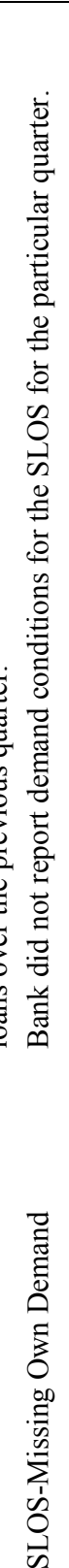 & 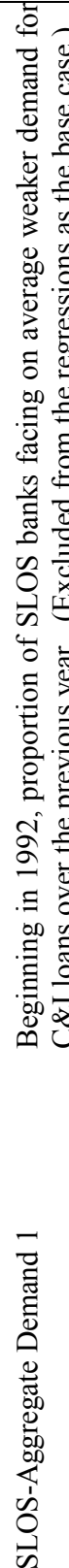 & 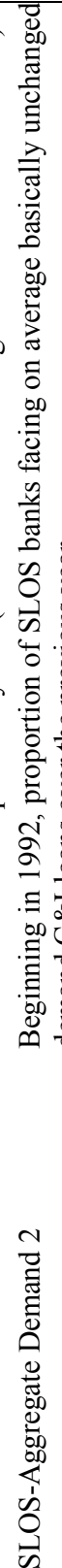 & 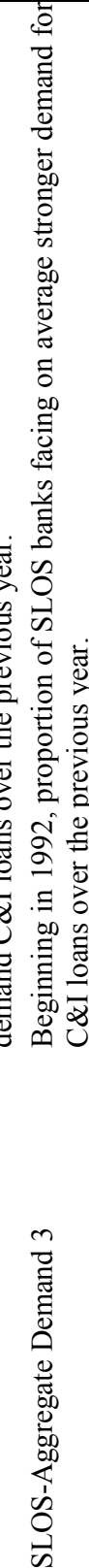 & 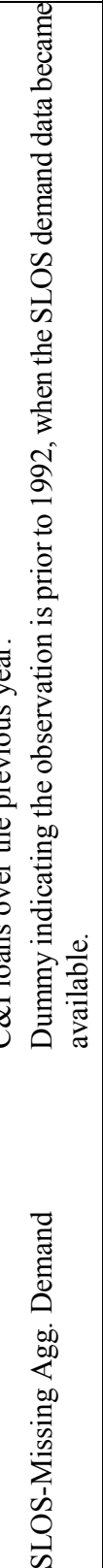 & 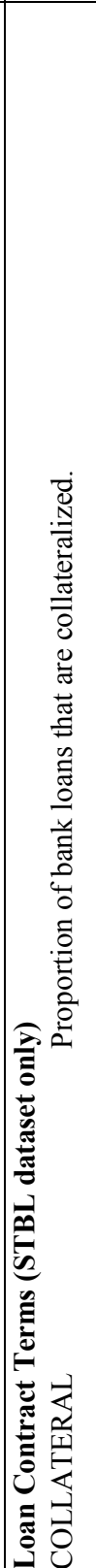 & 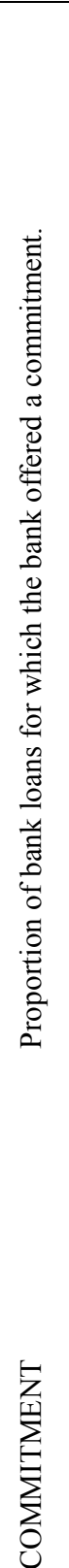 & 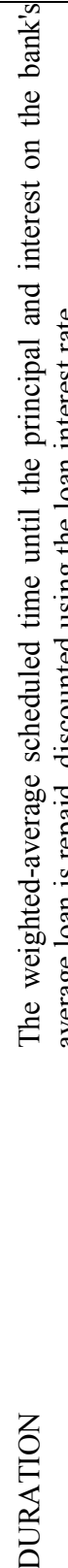 & 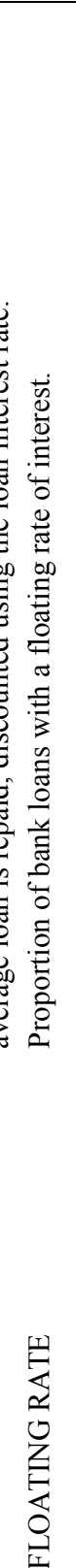 & 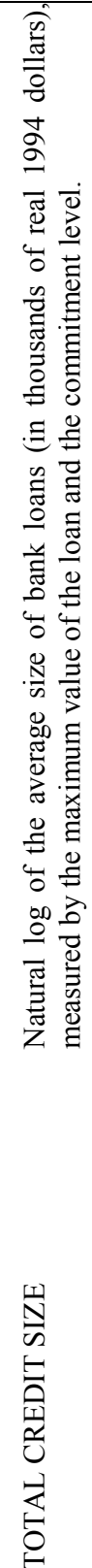 \\
\hline
\end{tabular}




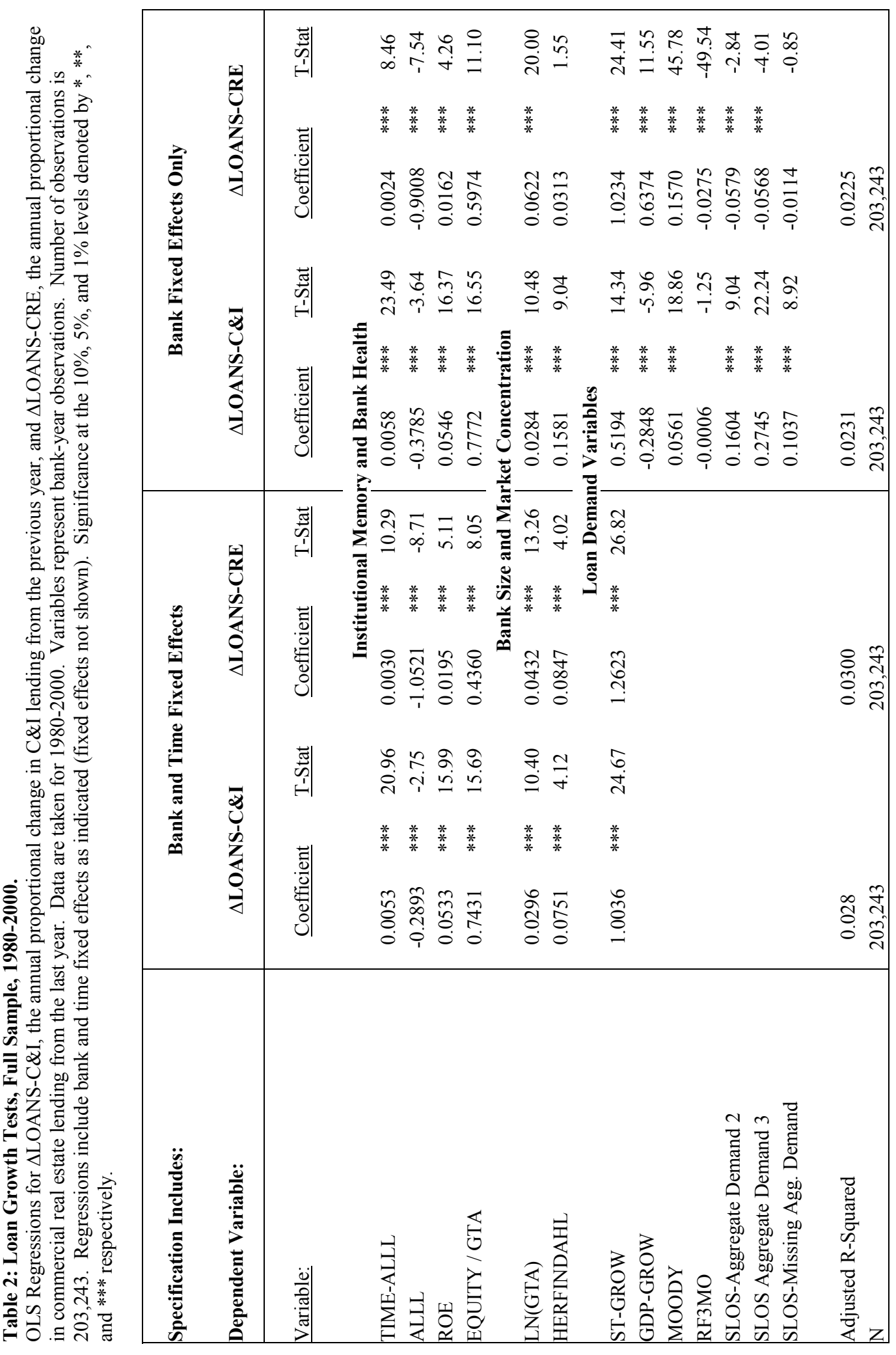




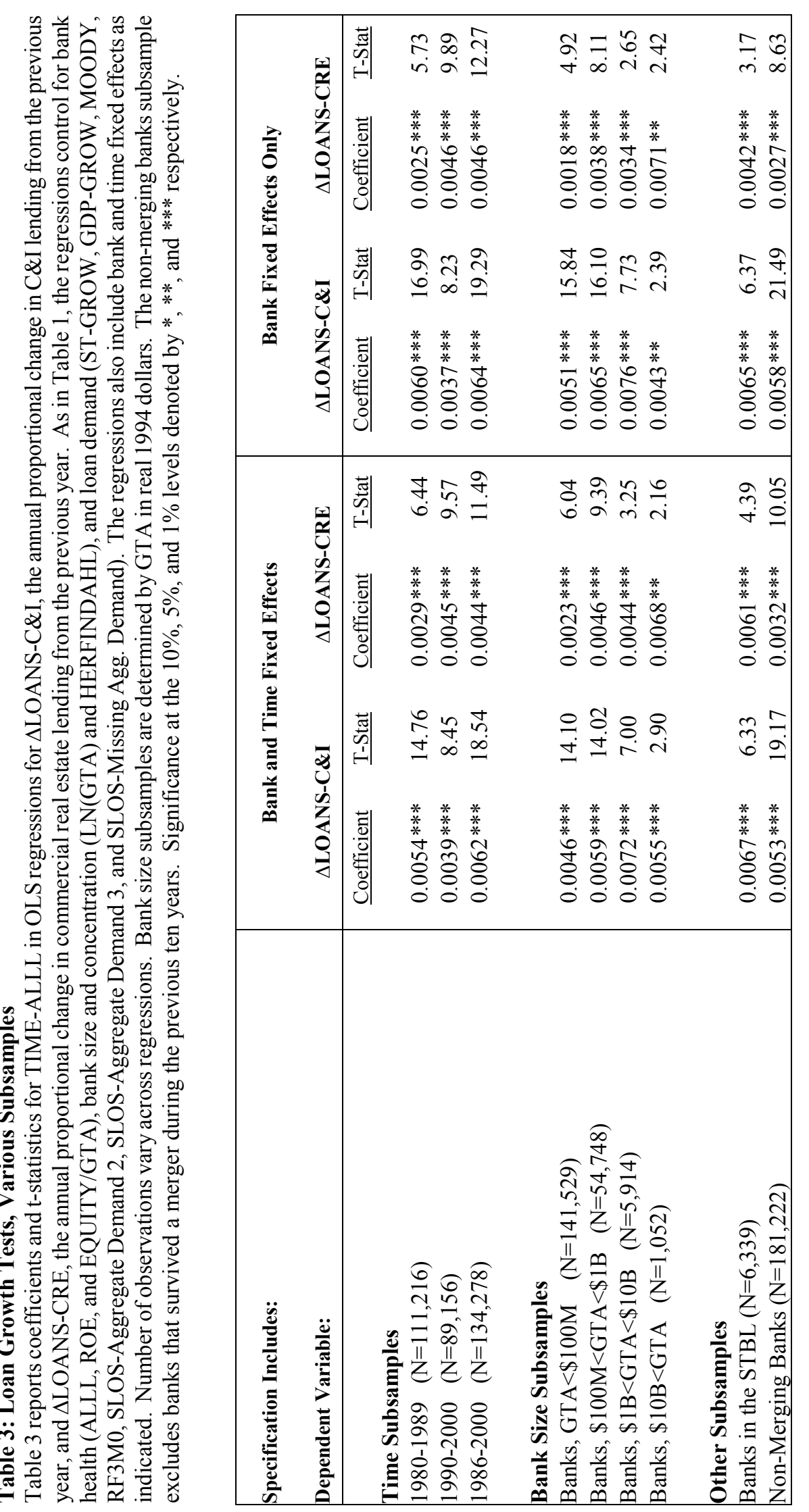




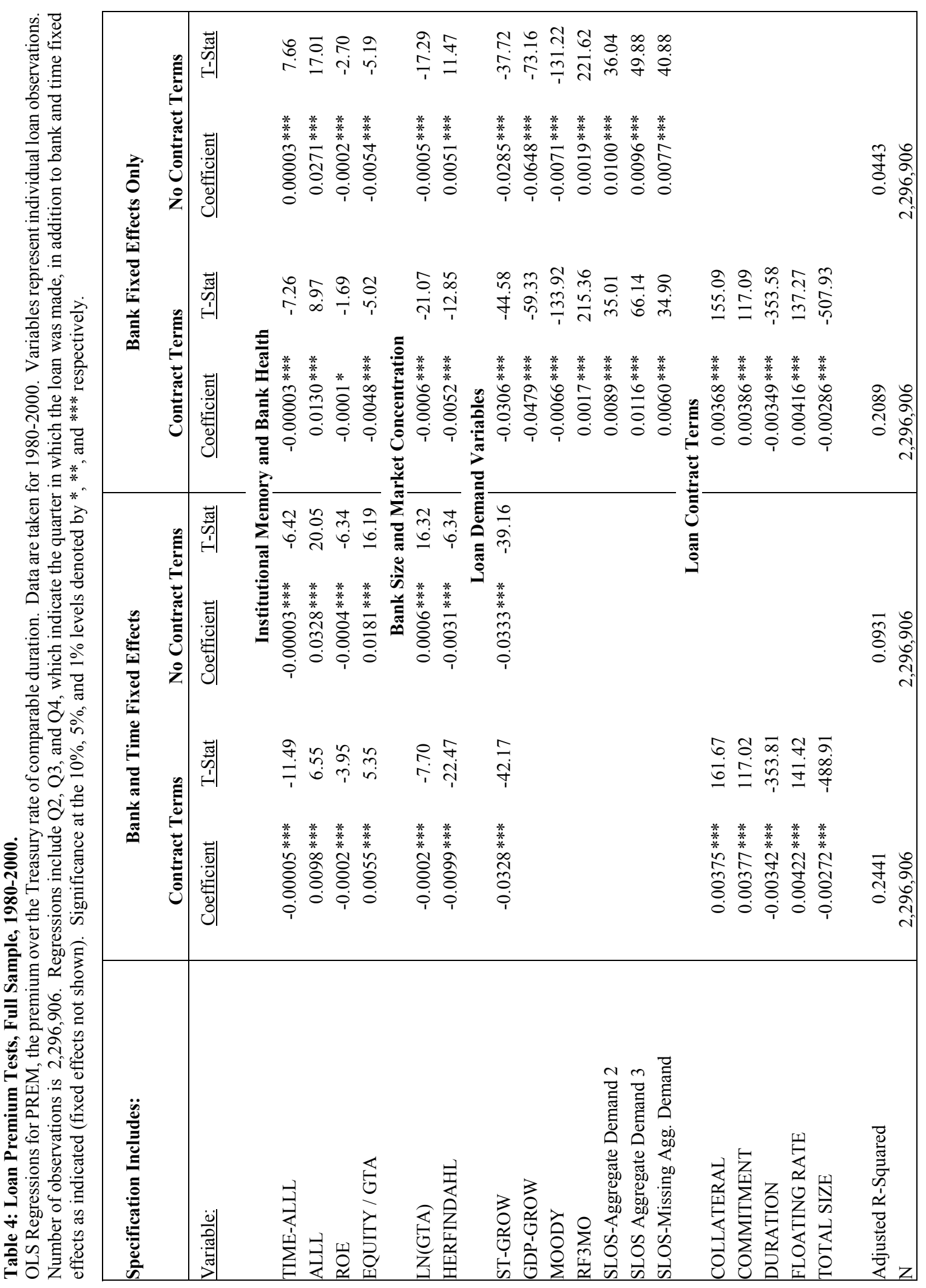




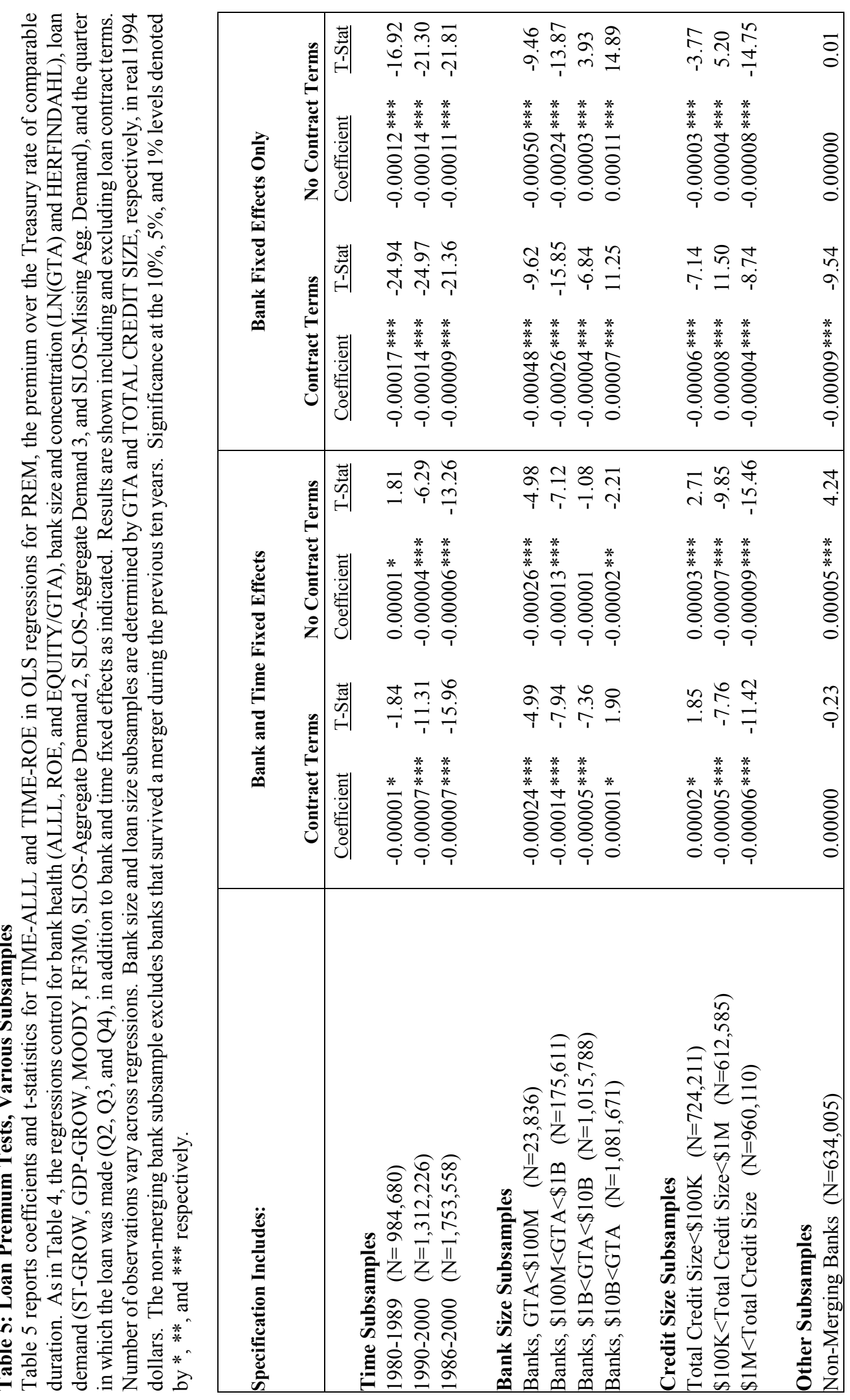




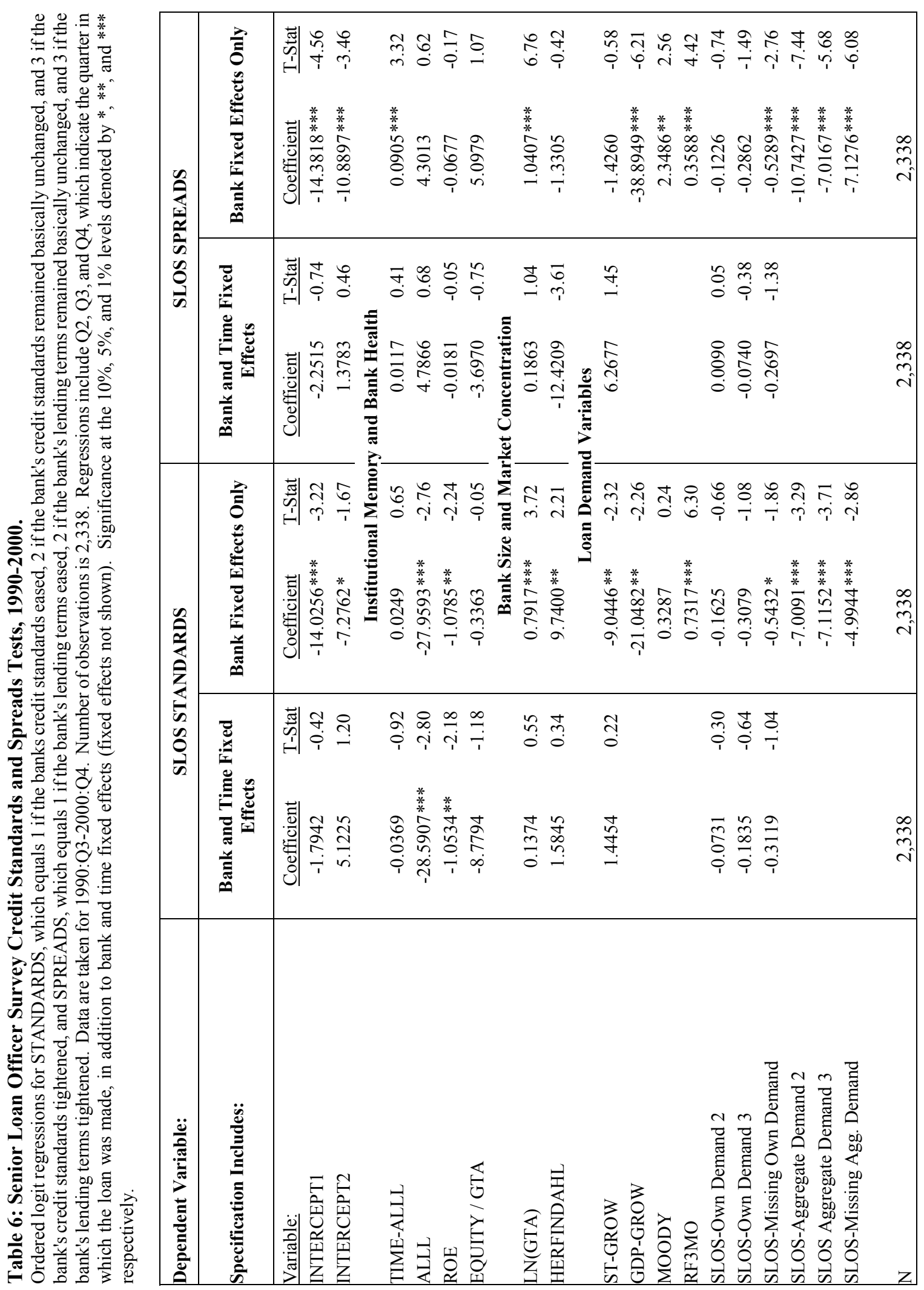

